Article

\title{
Mitigation of $\mathrm{CO}_{2} \mathrm{e}$ Emissions from the Municipal Solid Waste Sector in the Kingdom of Bahrain
}

\author{
Maha Alsabbagh \\ Department of Natural Resources and Environment, Arabian Gulf University, P.O. Box 26671, Manama, Bahrain; \\ mahamw@agu.edu.bh; Tel.: +973-17239421
}

Received: 19 June 2019; Accepted: 14 August 2019; Published: 20 August 2019

\begin{abstract}
Mitigating climate change to limit the global temperature increase (relative to pre-industrial temperatures) to $2{ }^{\circ} \mathrm{C}$ is receiving considerable attention around the world. Here, historical and future carbon dioxide equivalent $\left(\mathrm{CO}_{2} \mathrm{e}\right)$ emissions from municipal solid waste (MSW) in Bahrain were calculated using the revised Intergovernmental Panel on Climate Change (IPCC) 1996 and IPCC 2006 methods. The extent to which waste-to-energy (WtE) technologies can contribute to climate change mitigation was assessed by performing a multicriteria analysis. The results indicated that $\mathrm{CO}_{2} \mathrm{e}$ emissions from MSW in Bahrain have been increasing since the Askar landfill was constructed in 1986. Emission recalculations indicated that $\mathrm{CO}_{2} \mathrm{e}$ emissions from MSW contribute $6.2 \%$ of total emissions in Bahrain rather than the $11.6 \%$ reported in the second national communication. Methane emissions from MSW in 2030 are predicted to be $22-63 \mathrm{Gg}$. The WtE technologies anaerobic digestion and landfill gas recovery gave the best and gasification the worst multicriteria analysis model results. A database of WtE plants around the world should be compiled to allow decisions around the world to be based on best practices. The potential for maximizing energy recovery and decreasing costs needs to be investigated to allow WtE plants to compete better with renewable and nonrenewable energy sources.
\end{abstract}

Keywords: climate change; Gulf Cooperation Council (GCC); multicriteria analysis; waste-to-energy

\section{Introduction}

Climate change has been receiving considerable amounts of attention in recent years, particularly since the Paris Agreement and subsequent reports of national emissions and commitments to decreasing emissions. Attention has been focused on climate change mitigation and adaptation to climate change. Various sectors can make changes to mitigate climate change, and the sectors with the highest contributions to total carbon dioxide equivalent $\left(\mathrm{CO}_{2} \mathrm{e}\right)$ emissions should be prioritized.

The countries in the Gulf Cooperation Council (GCC), a political and economic alliance of six Arab countries founded in 1981, have relatively high energy and carbon intensities. The energy intensity figures for GCC countries range between 0.12 ton oil equivalent (toe)/thousand USD for the United Arab Emirates and 0.23 toe/thousand USD for Bahrain, with an average of 0.15 toe/thousand USD [1]. The average energy intensity in GCC countries exceeds the world's average of 0.13 toe/thousand USD [1]. The average carbon intensity in GCC countries is $0.35 \mathrm{~kg} \mathrm{CO}_{2} / \mathrm{USD}$, which also exceeds the world's average of $0.3 \mathrm{~kg} \mathrm{CO}_{2} / \mathrm{USD}$ [1]. The GCC countries have mainly focused on decreasing emissions caused by fossil fuel combustion (later called the energy sector). Almost all GCC countries have planned and implemented projects to improve energy efficiency and promote renewable energy [2-4]. Now that many of these projects have been implemented, focus is shifting toward mitigating $\mathrm{CO}_{2} \mathrm{e}$ emissions from other sectors, such as the waste sector.

Globally, $\mathrm{CO}_{2} \mathrm{e}$ emissions from the waste sector have almost doubled over the period 1970-2010, reaching more than $1400 \mathrm{Mt} \mathrm{CO}_{2} \mathrm{e}$ in 2010. Emissions from the waste sector make up $2.9 \%$ of the 
world's total $\mathrm{CO}_{2}$ e emissions, while emissions from developing countries are expected to grow over the coming years $[5,6]$. Several mitigation measures have been identified for the waste sector, including composting, improved landfill practices, recycling, energy recovery, and reducing waste generation [7]. A significant and growing body of literature has investigated the effectiveness of these measures in mitigating $\mathrm{CO}_{2} \mathrm{e}$ emissions from the waste sector, with a special focus on municipal solid waste (MSW) (e.g., References [8-11]).

Solid waste materials generated by households and during commercial activities are the main components of MSW [12]. There are $>2430$ MSW treatment plants and $>4500$ MSW incineration plants around the world [13]. Waste-to-energy (WtE) technologies can be grouped into thermochemical, biochemical, and chemical technologies, as shown in Figure 1. WtE technologies have been described thoroughly in the literature (e.g., References [14-20]). The requirements, pros, and cons of WtE technologies are summarized in Table 1 . WtE plants give energy recovery efficiencies between $18 \%$ and $23 \%$ for generating electricity and between $63 \%$ and $78 \%$ for producing heat, but an energy recovery efficiency of $83 \%$ can be achieved by simultaneously producing heat and power [17,21]. Most previous publications have been focused on ex ante assessments of WtE plants in terms of energy recovery potential, environmental impacts, and financial feasibility (e.g., References $[19,22-33])$. Few ex post assessments of WtE plants (e.g., References [21,34]), particularly in terms of whether expected energy recovery rates were achieved, have been published.

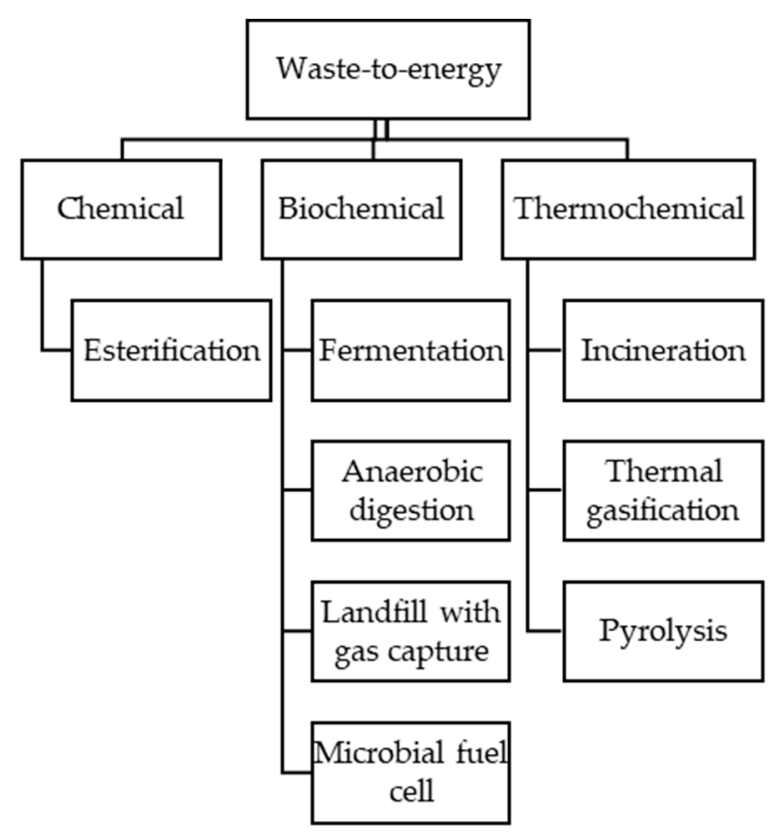

Figure 1. Classification of waste-to-energy (WtE) technologies [16].

Most GCC countries have identified sectors in which $\mathrm{CO}_{2} \mathrm{e}$ emissions can be mitigated in their nationally determined contributions. In particular, the potential for recovering energy from municipal solid waste (MSW) has been explored as a way of mitigating climate change. Several WtE projects have been planned in GCC countries, the majority in the United Arab Emirates (Table 2). The feasibility of using WtE technologies and the expected effectiveness of establishing WtE plants in GCC countries have been assessed in previous publications. Previous studies of WtE in GCC countries have focused on waste characterization [35-37], determining energy recovery potential [23,24,26,38], and selecting suitable WtE technologies [38]. Several methods have been used in the assessments of the waste management practices in GCC countries. A lifecycle assessment [39] and a driver-pressure-state-impact-response framework [40] have been used in Kuwait, a multicriteria analysis (MCA) has been used in Oman [38], and $\mathrm{WtE}$ technologies have been assessed in Saudi Arabia [41,42]. Anaerobic digestion (AD) was found to be the most suitable option for Saudi Arabia because of the large contribution of organic material 
to MSW in Saudi Arabia [43]. An MCA indicated that AD was also most appropriate for Oman [38]. However, a financial analysis indicated that AD was not suitable for the United Arab Emirates and that incineration would have a payback period of 19 years [24]. 
Table 1. Pros and cons of selected waste-to-energy technologies [14,16,17,22,29,44-47].

\begin{tabular}{|c|c|c|c|c|}
\hline Technology & Incineration & Anaerobic Digestion & Landfill Gas & Gasification \\
\hline Brief description & $\begin{array}{l}\text { - Direct burning of waste at } 800-1000{ }^{\circ} \mathrm{C} \\
\text { Products: heat, power, dust, ash, } \\
\text { air pollutants }\end{array}$ & $\begin{array}{l}\text { Biochemical conversion of organic } \\
\text { waste to produce biogas } \\
\text { - Processing organic waste takes } \\
\sim 15-30 \text { days } \\
\text { - Produces methane }(65 \%), \mathrm{CO}_{2}(35 \%), \\
\text { and some air pollutants } \\
\text { Products: biomethane, heat, power, } \\
\text { nutrient-rich digestate }\end{array}$ & $\begin{array}{l}\text { - Anaerobic decomposition of } \\
\text { biodegradable waste in a } \\
\text { sanitary landfill } \\
\text { Wells with pipes in the landfill are } \\
\text { used to retrieve the gas }\end{array}$ & $\begin{array}{l}\text { - } \quad \text { Converts waste containing carbon } \\
\text { into synthesis gas } \\
\text { - } \quad \text { Temperature of } 750{ }^{\circ} \mathrm{C} \\
\text { - } \quad \text { Methane, hydrogen, and other } \\
\text { - } \quad \text { Pydrocarbons are produced } \\
\text { eacesses around } 100 \mathrm{t} \text { of waste } \\
\text { - } \quad \text { Products: power, heat, ash }\end{array}$ \\
\hline Pros & $\begin{array}{l}\text { - Inputs can include whole waste or waste } \\
\text { with recyclable material removed } \\
\text { - } \quad \text { Can decrease the waste volume by } 80 \% \\
\text { - Does not require a large land area }\end{array}$ & $\begin{array}{ll} & \text { Economically feasible } \\
\text { - } & \text { Air pollutants can be controlled } \\
\text { - } & \text { Suss complicated than other methods } \\
& \text { waste per day } \\
\text { - } & \text { Uses an enclosed system, which } 2 \text { tonnes of } \\
& \text { allows emissions to be controlled } \\
\text { - } & \text { No power is required } \\
\text { - } & \text { No odors are produced } \\
\quad & \text { Little land is required }\end{array}$ & $\begin{array}{l}\text { - Cheapest option } \\
\text { - } \quad \text { Got a complex process } \\
\text { power or directly to produce heat }\end{array}$ & $\begin{array}{l}\text { - } \quad \text { Fast } \\
\text { - } \quad \text { Little air pollution caused } \\
\text { - } 50 \%-90 \% \\
\text { - Synthesis gas can be used to generate } \\
\text { electricity or produce fuels, chemicals, } \\
\text { and synthesis natural gas }\end{array}$ \\
\hline Cons & $\begin{array}{ll}\text { - } & \text { Old technology } \\
\text { - } & \text { Produces large amounts of } \\
\text { - } & \text { gateenhouse gases systems allow air pollutant } \\
\text { emissions to be controlled to comply with } \\
\text { emissions standards } \\
\text { - } \quad \begin{array}{l}\text { Not economically feasible for }<100 \text { tonnes } \\
\text { of waste per day }\end{array} \\
\text { - } \quad \text { Requires waste with a high calorific value } \\
\text { High capital cost }\end{array}$ & $\begin{array}{ll}\text { - } & \text { Requires organic waste } \\
\text { - } & \text { Waste needs to be segregated } \\
\text { Biogas needs to be treated before use }\end{array}$ & $\begin{array}{l}\text { - Low power generation efficiency } \\
\text { - } \quad \text { Requires large land area } \\
\text { runoffion may be caused by surface } \\
\text { - Leachates may be released into } \\
\text { the groundwater } \\
\text { - Spontaneous explosions can occur } \\
\text { because of methane accumulation }\end{array}$ & $\begin{array}{l}\text { - } \quad \text { Complex process } \\
\text { Requires recyclable material and } \\
\text { inorganic waste to be removed } \\
\text { - Poor energy recovery associated with } \\
\text { waste with a high moisture content } \\
\text { - Cleaning the synthesis gas is } \\
\text { challenging for large plants }\end{array}$ \\
\hline
\end{tabular}


Table 2. Waste-to-energy projects in Gulf Cooperation Council (GCC) countries.

\begin{tabular}{|c|c|c|c|c|c|}
\hline Country & Project & $\begin{array}{l}\text { Capacity } \\
\text { (kt/year) }\end{array}$ & $\begin{array}{c}\text { Installed Power } \\
\text { Generation Capacity } \\
\text { (MW) }\end{array}$ & $\begin{array}{l}\text { Cost (Million } \\
\text { USD) }\end{array}$ & $\begin{array}{c}\text { Operational } \\
\text { Year }\end{array}$ \\
\hline \multirow{5}{*}{$\begin{array}{l}\text { United Arab } \\
\text { Emirates }\end{array}$} & Sharjah & 300 & 30 & 220 & 2020 \\
\hline & Sharjah (Sajja area) & 400 & 80 & & \\
\hline & Ras Al Khaimah & - & 2 & 32 & \\
\hline & Dubai (Al Warsan) & 1825 & 185 & 545 & 2020 \\
\hline & Abu Dhabi & - & 100 & 850 & \\
\hline Bahrain & Askar & 390 & 25 & 480 & \\
\hline Kuwait & Kabd & 1195 & 100 & 756 & \\
\hline Oman & & 803 & 50 & 750 & 2023 \\
\hline
\end{tabular}

Note: Saudi Arabia has set an ambitious target of $3 \mathrm{GW}$ for WtE facilities in 2030.

This paper aims to achieve two main objectives:

- To calculate historical $\mathrm{CO}_{2} \mathrm{e}$ emissions and predict future emissions from MSW in Bahrain; and

- To assess various WtE technologies in terms of effectiveness and appropriateness for use in Bahrain.

The following section provides a brief on the case study, i.e., Bahrain. The methods used to achieve the research objectives are described in the third section. The results of the analysis are presented and discussed in the fourth section. Conclusions are drawn and recommendations are presented in the fifth section.

\section{The Case Study: Bahrain}

Bahrain, the smallest GCC country by area and population, is the only GCC country that has not proposed mitigating $\mathrm{CO}_{2}$ e emissions from the MSW sector either in nationally determined contributions or national communications to the United Nations Framework Convention on Climate Change. $\mathrm{CO}_{2} \mathrm{e}$ emissions from the waste sector in Bahrain are increasing (Figure 2), and the total amount of waste generated is also increasing by an average of $10 \%$ annually (Figure 3). These increases agree with increases in the population and gross domestic product, where the coefficient of determination is 0.922 and 0.814, respectively (Figure 4). MSW contributed $~ 55 \%$ of total waste in Bahrain in 2016. This contribution has been decreasing temporally because the contributions of other types of waste (particularly construction waste) have increased (Figure 3). Nonetheless, the amount of MSW produced has been increasing by $6 \%$ per year on average (Figure 3). MSW produced in Bahrain is mainly organic material, plastic, and paper (Figure 5). The contribution of plastic to MSW in Bahrain was considerably higher in 2017 than in previous years (Figure 5). The percentage of organic material in MSW in Bahrain is almost similar to that of other GCC countries (Figure 6). However, the share of the plastic waste in Bahrain is considerably higher and the share of the paper waste is lower than that of other GCC countries.

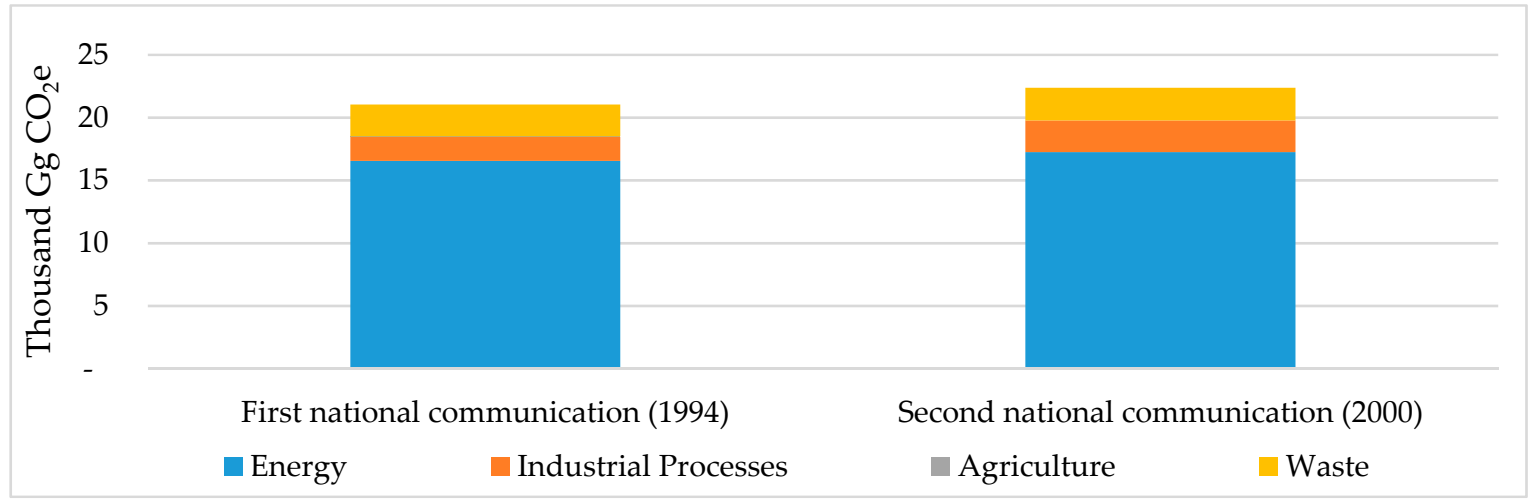

Figure 2. $\mathrm{CO}_{2} \mathrm{e}$ emissions from different sectors in Bahrain, from the first and second national communications (NCs) [48,49]. 


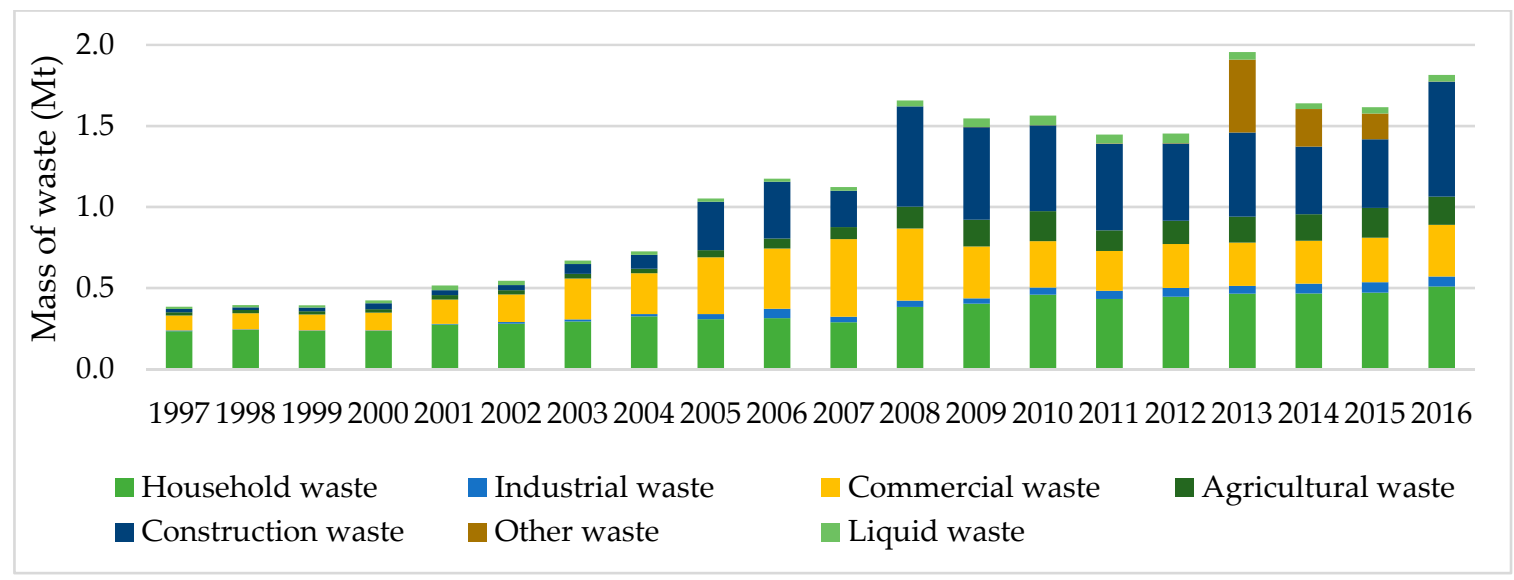

Figure 3. Total amounts of waste produced and the contributions of different types of waste in Bahrain between 1997 and 2016 [50,51].

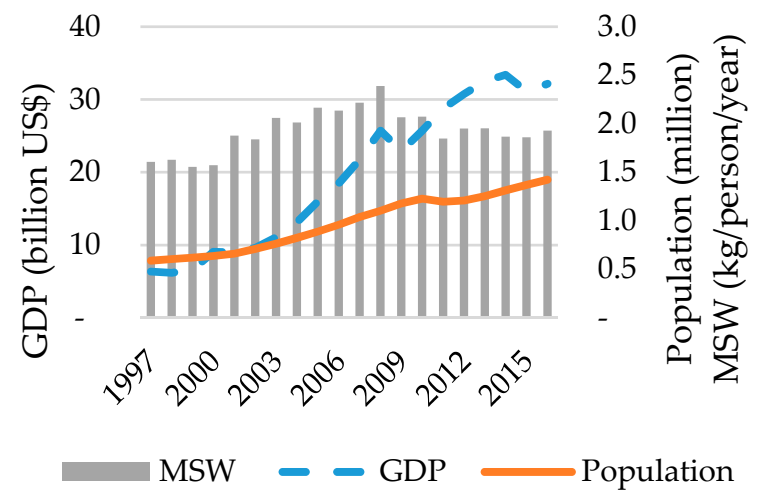

(a)

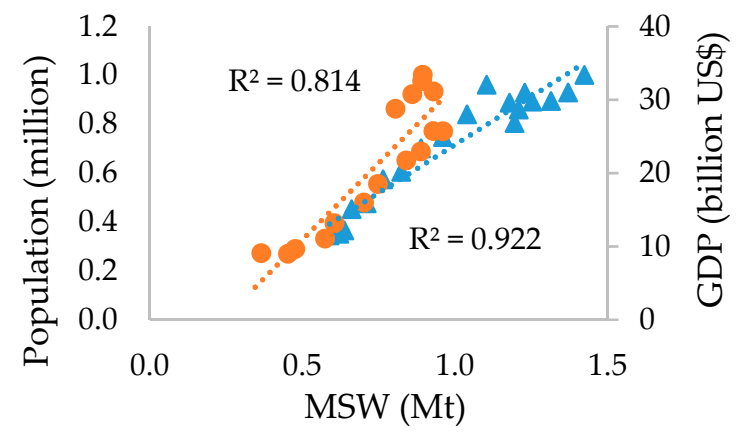

$\triangle$ MSW and Population $\bullet$ MSW and GDP

(b)

Figure 4. (a) Amount of municipal solid waste (MSW) produced, population, and gross domestic product (GDP) in Bahrain between 1997 and 2016 [50-52] and (b) relationships between the population and GDP and the amount of MSW produced.

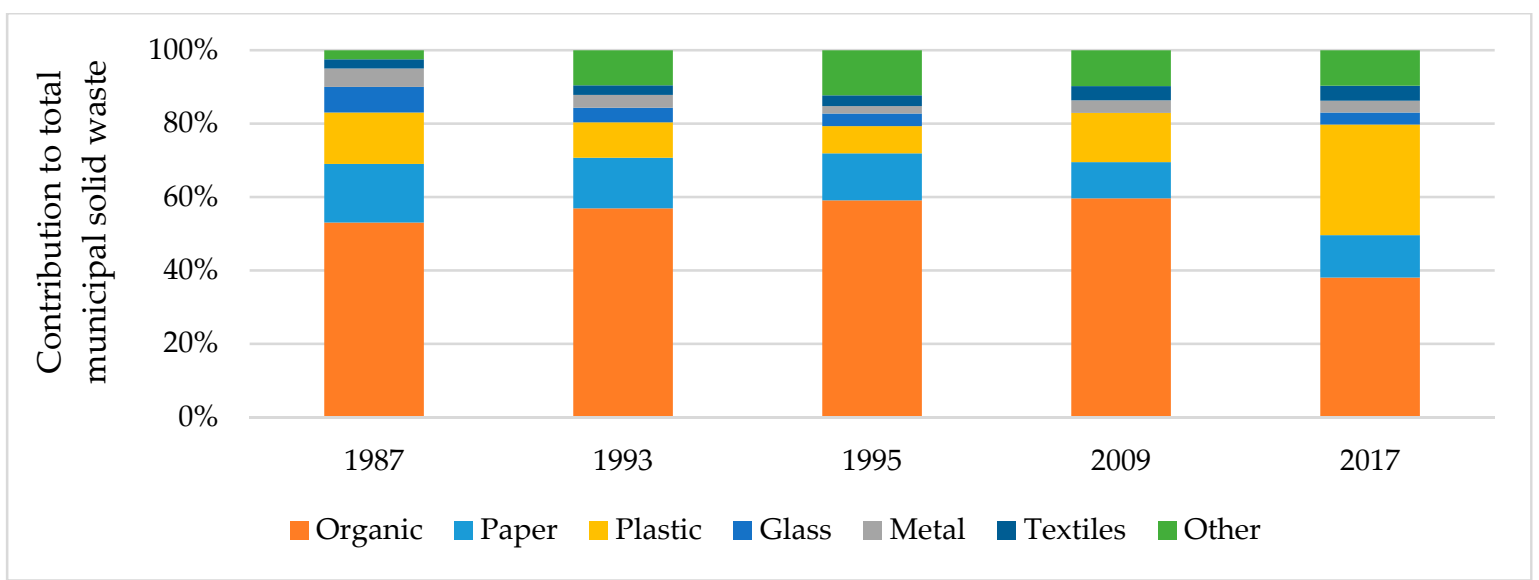

Figure 5. Composition of municipal solid waste produced in Bahrain between 1987 and 2017 [53-55]. 


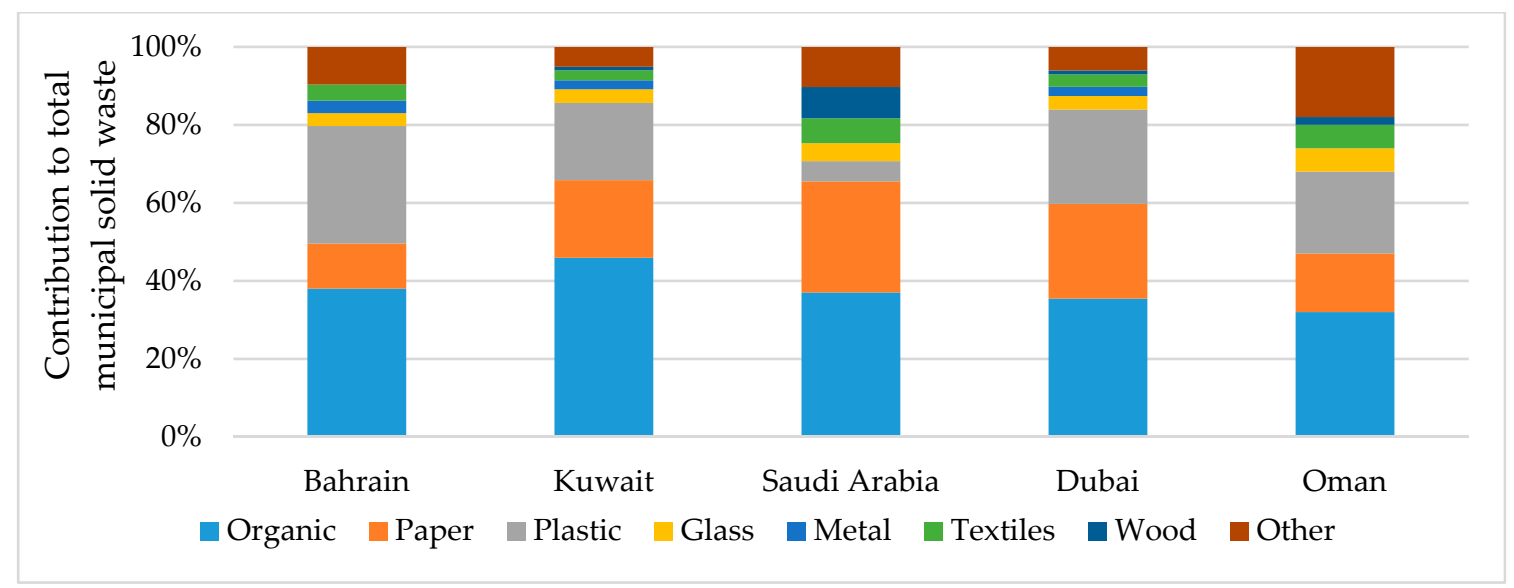

Figure 6. Composition of municipal solid waste produced in selected Gulf Cooperation Council countries $[26,38,55-57]$.

Most of the MSW produced in Bahrain is sent to the Askar landfill, which is a controlled but not engineered landfill [53]. The Askar landfill will be full in only six years. A waste management hierarchy has therefore been developed. Recycling and energy recovery are important parts of the Bahrain national waste management strategy that was approved by the Cabinet of Ministers in February 2018. The strategy involves eight projects to deal with different types of waste. Four of the projects are directly relevant to MSW. These projects are the following:

- Recycling paper, aluminum, and iron;

- Waste-to-energy projects;

- Converting the remainder of the Asker landfill into a sanitary engineered landfill; and

- Initiating a center (called Estidama, which means sustainability) responsible for controlling processes related to waste, including monitoring processes, providing statistics, and continuing the implementation of the national waste management strategy.

There have been few peer-reviewed publications that have focused on waste in Bahrain. Studies that have been published have focused on estimating methane emissions from the Asker landfill [58], characterizing waste [53], and identifying suitable locations for new landfills [59]. However, there have been no peer-reviewed articles on the assessment of WtE technologies in Bahrain.

Increasing attention is being paid to MSW in Bahrain in terms of waste management, $\mathrm{CO}_{2} \mathrm{e}$ emissions, and energy recovery. However, planning to mitigate climate change has only been started in the wastewater treatment sector. A sludge-to-energy project has been proposed in the Bahrain national renewable energy action plan. There are no planned climate change mitigation projects for MSW. A project in Askar was recently suggested, but no progress has been made so far (Table 2). Therefore, this paper is of extreme importance for environmental policymaking in Bahrain, contributing new data on the assessment of WtE technologies.

\section{Methods}

\subsection{Calculating Historical $\mathrm{CO}_{2}$ e Emissions and Predicting Future Emissions from MSW}

In the second national communication, it was suggested that $124 \mathrm{Gg}$ of methane (equivalent to $\sim 2600 \mathrm{Gg} \mathrm{CO}_{2} \mathrm{e}$ ) is emitted by solid waste disposed on land in Bahrain [49]. The $\mathrm{CO}_{2} \mathrm{e}$ value was recalculated here to ensure that the value reported in the second national communication was correct and to assess temporal trends in $\mathrm{CO}_{2} \mathrm{e}$ emissions from waste. Two methods were used in this paper to calculate emissions for the period 1986-2016. The revised Intergovernmental Panel on Climate Change (IPCC) 1996 method was used to validate the second national communication results (for which the same method was used). The IPCC 2006 method was also used because it is the most recent method 
recommended for calculating $\mathrm{CO}_{2} \mathrm{e}$ emissions from waste. The revised IPCC 1996 method is based on methane commitments or the total amount of methane generated. The IPCC 2006 method is based on a first-order decay model that requires detailed input data for more than 10 years [60]. Methane emissions were calculated using Equation (1), from the revised IPCC 1996 method [61]:

$$
\text { Methane emissions }(\mathrm{Gg} / \text { year })=\left(\mathrm{MSW}_{\mathrm{T}} \times \mathrm{MSW}_{\mathrm{F}} \times \mathrm{MCF} \times \mathrm{DOC} \times \mathrm{DOC}_{\mathrm{F}} \times \mathrm{F} \times \frac{16}{12}-\mathrm{R}\right) \times(1-\mathrm{OX}) .
$$

In Equation (1), $M S W_{T}$ is the total amount of MSW generated, $M S W_{F}$ is the fraction of the MSW disposed of in the landfill of interest, $M C F$ is the methane correction factor, DOC is the degradable organic carbon content, $D O C_{F}$ is the dissimilation fraction for the DOC, $F$ is the methane fraction for the landfill gas, $R$ is the amount of methane recovered, and $O X$ is the oxidation factor.

As for the IPCC 2006 method, the following equations were used [62]:

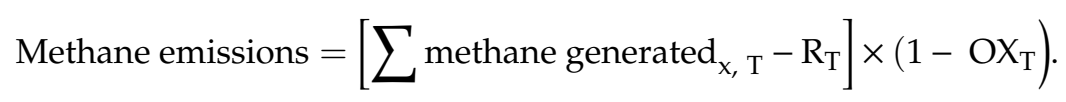

In Equation (2), $T$ is the inventory year, $x$ is the waste type, $R_{T}$ is the amount of methane recovered in year $T$, and $O X_{T}$ is the oxidation factor. The generated methane value was calculated using Equations (3)-(6):

$$
\mathrm{DDOCm}=\mathrm{W} \times \mathrm{DOC} \times \mathrm{DOC}_{\mathrm{f}} \times \mathrm{MCF} .
$$

In Equation (3), $D D O C m$ is the mass of decomposable DOC deposited, $D O C$ is the amount of degradable organic carbon deposited in the year of interest as a fraction $\left(\mathrm{Gg} C / \mathrm{Gg}\right.$ waste), $D O C_{f}$ is the fraction of DOC that could be decomposed, and MCF is the methane correction factor (as a fraction) for aerobic decomposition in the year the waste was deposited. Equation (4) is

$$
\text { DDOCma }_{\mathrm{T}}=\text { DDOCmd }_{\mathrm{T}}+\left(\text { DDOCma }_{\mathrm{T}-1} \times \mathrm{e}^{-\mathrm{k}}\right) .
$$

In Equation (4), $D D O C m a_{T}$ is the accumulated mass (in $\mathrm{Gg}$ ) of decomposable DOC in a landfill at the end of inventory year $T, D D O C m a_{T-1}$ is the accumulated mass (in $\mathrm{Gg}$ ) of decomposable DOC in a landfill at the end of year $T-1$, and $D D O C m d_{T}$ is the mass (in $\mathrm{Gg}$ ) of decomposable DOC in a landfill in year $T$. Equation (5) is

$$
\text { DDOCm decomp }_{\mathrm{T}}=\text { DDOCma }_{\mathrm{T}-1} \times\left(1-\mathrm{e}^{-\mathrm{k}}\right) .
$$

In Equation (5), DDOCm decomp $p_{T}$ is the mass (in Gg) of decomposable DOC decomposed in a landfill in year $T$, and $k$ is the reaction constant calculated using the equation $k=\operatorname{In}(2) / t_{1 / 2}\left(y^{-1}\right)$, where $t_{1 / 2}$ is the half-life in years. Equation (6) is

$$
\text { Methane generated } \text { TDOCm decomp }_{\mathrm{T}} \times \mathrm{F} \times 16 / 12 \text {. }
$$

In Equation (6), $F$ is the methane fraction by volume, and $16 / 12$ is the $\mathrm{CH}_{4} / \mathrm{C}$ molecular mass ratio.

Projections of $\mathrm{CO}_{2} \mathrm{e}$ emissions from MSW between 2017 and 2030, using 2016 as the base year, were made applying the IPCC 2006 method and using DOC and MSW generation as the two main variables. The minimum and maximum $D O C$ values identified in previous MSW composition surveys (Figure 5) were used. Future MSW generation was determined using Equation (7):

$$
\text { Future } \mathrm{MSW}_{\mathrm{T}}=\text { Per capita } \mathrm{MSW}_{\mathrm{T}} \times \text { Population projection. }
$$

The mean (1.9 kg/capita/day), minimum (1.6 kg/capita/day), and maximum (2.4 kg/capita/day) amounts of MSW produced per capita between 1986 and 2016 and population projections prepared by the government and the World Bank were used [50,63] (Figure 7). This allowed future $\mathrm{CO}_{2} \mathrm{e}$ emissions from MSW to be predicted using different assumptions. 


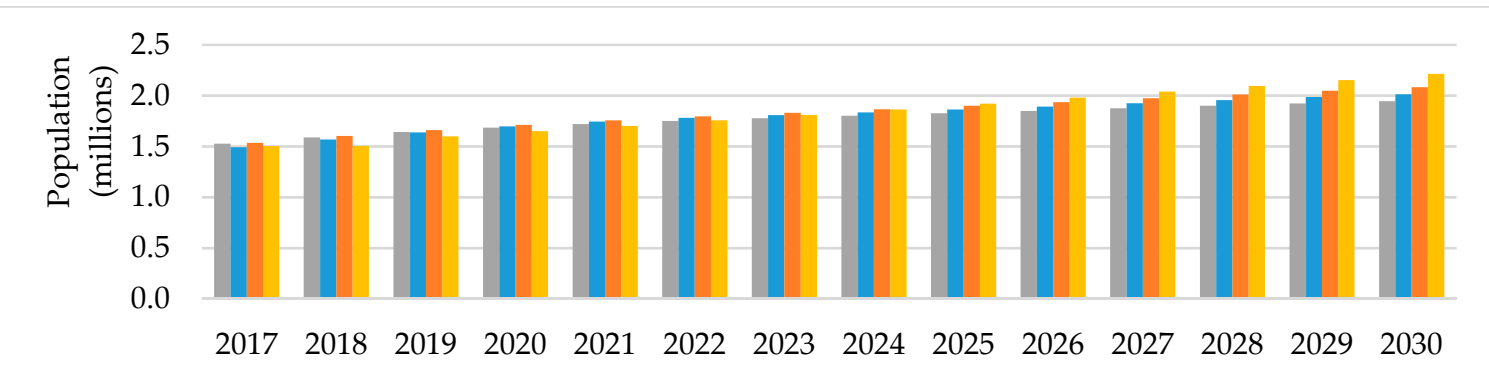

World Bank low variant $\square$ World Bank medium variant $\square$ World Bank high variant $\square$ Government

Figure 7. Population projections used in the determination of future MSW [50,63].

\subsection{Assessing Various WtE Technologies in Terms of Effectiveness and Appropriateness for Use in Bahrain}

The energy recovery potentials for the main $\mathrm{WtE}$ technologies were determined using the equations shown below for incineration, $\mathrm{AD}$, gasification, and landfill gas $[22,29,64]$. The lower calorific values (LCVs) were taken from a previous publication [26] and are shown in Table 3.

Table 3. Energy contents of various types of waste [26].

\begin{tabular}{cc}
\hline Type of Waste & Energy Content (Btu/Ib) \\
\hline Mixed paper & 6800 \\
Mixed food waste & 2400 \\
Mixed plastic & 14,000 \\
Textiles & 8100 \\
Waste hardwood & 6500 \\
\hline
\end{tabular}

The energy recovery potential for incinerating MSW was calculated using the equation

$$
\mathrm{ERP}=\mathrm{M} \times \mathrm{LCV}_{\mathrm{MSW}} \times \eta
$$

where $E R P$ is the energy recovery potential, $M$ is the total mass of solid waste, $L C V_{M S W}$ is the LCV of the waste, and $\eta$ is the efficiency of the process. Several efficiency values $(15 \%, 22 \%, 26 \%, 33 \%, 35 \%$, and $40 \%$ ) from previous publications were used to indicate the range of energy recovery potentials that could be achieved.

The energy recovery potential for $\mathrm{AD}$ was calculated using the equation

$$
\mathrm{ERP}=\mathrm{f} \times \mathrm{M}_{\mathrm{OFSW}} \times \mathrm{LCV}_{\text {biogas }} \times \eta,
$$

where $f$ is the fraction of organic waste, $M_{O F S W}$ is the amount of methane generated from the organic fraction of the solid waste, $L C V_{\text {biogas }}$ is the $\mathrm{LCV}$ for the biogas caused by the presence of methane, and $\eta$ is the electrical efficiency of the system $(20 \%, 26 \%$, or $40 \%)$. The methane generation rate from the biogas was $71 \mathrm{kWh} / \mathrm{Nm}^{3}$ [64], and the LCV for biogas was $21.51 \mathrm{MJ} / \mathrm{m}^{3}$ (i.e., $5.97 \mathrm{kWh} / \mathrm{m}^{3}$ ) [22].

The energy recovery potential for gasification was calculated using the equation

$$
\mathrm{ERP}=\mathrm{G} \times \mathrm{R}_{\mathrm{f}} \times \mathrm{LCV}_{\mathrm{MSW}} \times \eta,
$$

where $G$ is the amount of waste treated each year, $R_{f}$ is the percentage of waste rejected after being treated, and $\eta$ is the electrical efficiency of the system ( $23 \%$ or $30 \%)$. The percentage of waste rejected after being treated was $72.51 \%$ [22]. 
The energy recovery potential for landfill gas was calculated using the equation

$$
\mathrm{ERP}=\mathrm{LCV}_{\text {biogas }} \times \mathrm{Q}_{\mathrm{CH} 4} \times \gamma \times \eta,
$$

where $L C V_{\text {biogas }}$ is the LCV of the biogas caused by the presence of methane, $Q_{C H 4}$ is the amount of methane produced each year, $\gamma$ is the efficiency of the biogas recovery system (80\%), and $\eta$ is the efficiency of the electricity generation system (33\%). The amount of methane was determined from the IPCC 2006 greenhouse gas emissions inventory, as explained above, and the LCV of the biogas was $5.97 \mathrm{kWh} / \mathrm{m}^{3}$ [22].

A multicriteria Analysis (MCA) was applied to assess the effectiveness of WtE technologies. MCA is an approach that has been applied in environmental assessments and policymaking $[65,66]$. There are several MCA methods, such as linear additive models, outranking methods, multi-attribute utility theory (MAUT), and analytic hierarchy process (AHP). The processes, data requirement, and the results of each MCA method differ. However, the main stages of MCA are almost the same: establishing the context, identifying alternatives, identifying assessment criteria and their weights, and assigning scores to the alternatives against the assessment criteria [66]. The result of an MCA can be a single most preferred alternative, a ranking order of the alternatives, or a shortlist of the alternatives [67].

The adoption of an MCA enables assessments of alternatives to be conducted based on multiple quantitative and qualitative criteria [68,69]. Additionally, an MCA can encompass the results of several methods, including economic analysis and environmental assessments. However, the use of MCAs has a number of limitations. The limitations include possible subjectivity in assigning criteria weights and performance scores, in addition to limitations related to dealing with uncertainty.

In this study, a linear additive model was applied, where a simple MCA matrix was built and WtE technologies were assessed based on four main criteria: environmental, economic, social, and other criteria (Figure 8) (for details on the method, please see Reference [66]). The selection of the assessment criteria and subcriteria was in light of relevant literature [38,70]. The assessment was based on the energy recovery figures calculated using Equations (8)-(11), along with the costs of using WtE technologies and various qualitative criteria, which were taken from published studies [14,16,64,71-73]. A scale of 0-100 was used, with 0 meaning that the technology is not recommended and 100 being the highest score (Figure 9).

Several criteria and criteria weights were used to build four sets of MCA, as follows:

- Equal weights were used for the assessment criteria;

- Different weights (based on Reference [38]) for the criteria were used to determine whether using different weights for the different criteria would change the ranking order of the WtE options (criteria weights: environmental $=0.45$, economic $=0.31$, social criteria $=0.05$, and other criteria $=$ $0.19)$;

- Criteria from Reference [14] were used to reflect the current MSW status in Bahrain using equal weights for the criteria; and

- Criteria from Reference [14] were used to reflect the MSW status in Bahrain in the near future using equal weights for the criteria.

The aggregated scores were calculated using the equation [66]

$$
\mathrm{S}_{\mathrm{i}}=\mathrm{w}_{1} \mathrm{~s}_{\mathrm{i} 1}+\mathrm{w}_{2} \mathrm{~s}_{\mathrm{i} 2}+\ldots+\mathrm{w}_{\mathrm{n}} \mathrm{s}_{\mathrm{in}}=\sum_{\mathrm{j}=1}^{\mathrm{n}} \mathrm{w}_{1} \mathrm{~s}_{\mathrm{ij}},
$$

where $i$ is the WtE technology, $j$ is a criterion, $n$ is the number of criteria, $s$ is the score, and $w$ is the weight of criterion $j$. The $\mathrm{WtE}$ technology rank orders were compared using the Friedman nonparametric test. The number of sets was relatively small, but it has previously been suggested that this test could be used [74-76]. 


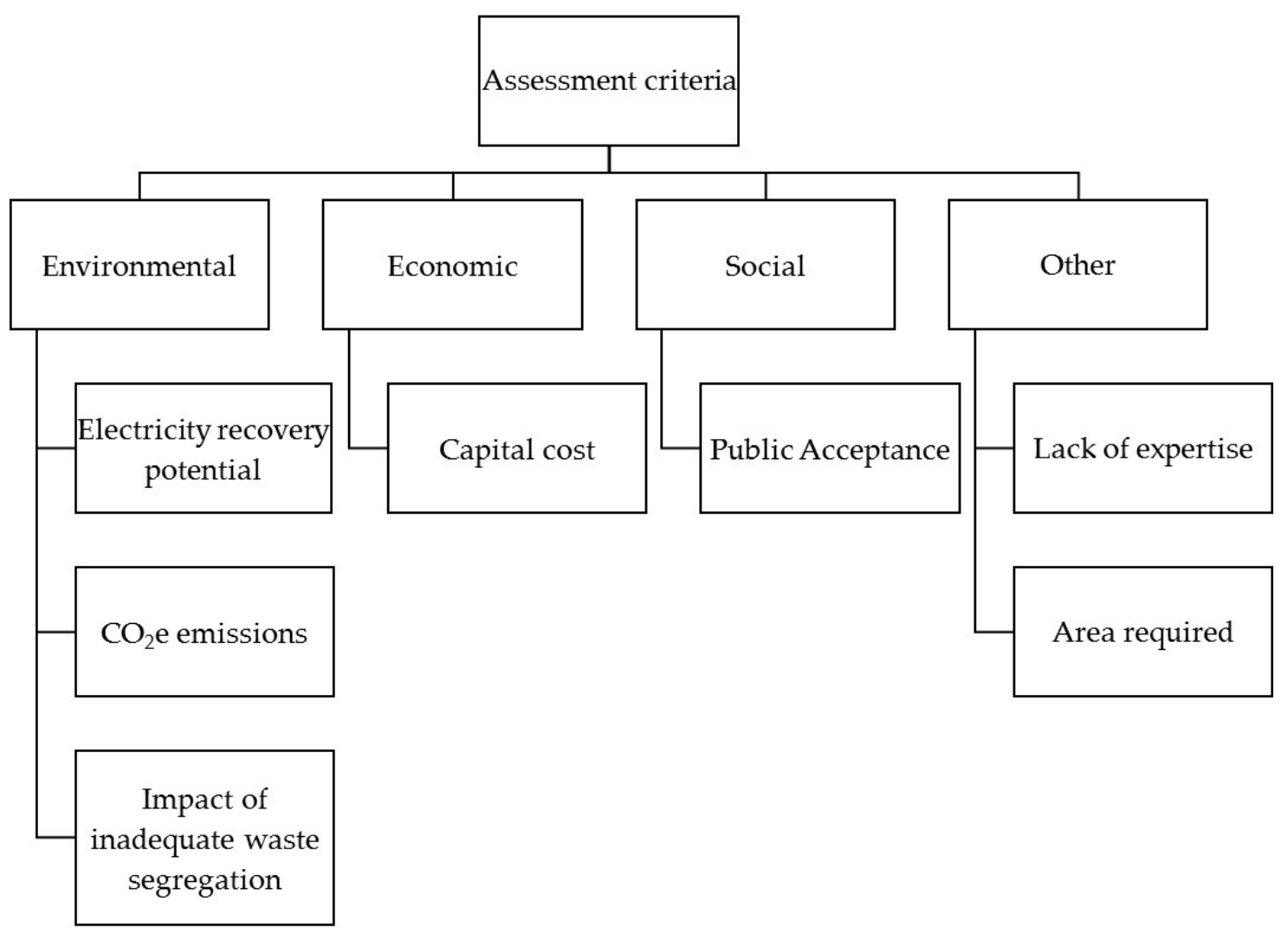

Figure 8. Assessment criteria used for the first and second multiple criteria analysis models.
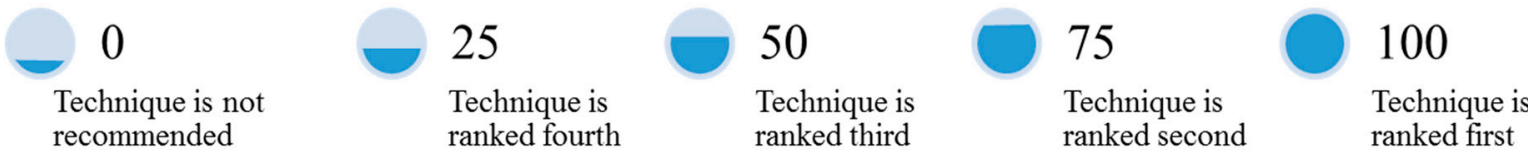

Figure 9. Scale used in the multiple criteria analysis models.

\section{Results and Discussion}

\subsection{Historical $\mathrm{CO}_{2}$ e Emissions from MSW and Predicted Future Emissions}

Each calculation method indicated that methane emissions increased over time. Methane emissions from the Asker landfill since the landfill opened in 1986 are shown in Figure 10. The revised IPCC 1996 calculations indicated the total methane emissions expected to be released from MSW, but the IPCC 2006 method involved the assumption that the methane would not be emitted all at once. The two methods therefore gave different annual methane emissions for the landfill.

The revised IPCC 1996 method was used to calculate methane emissions for the second national communication, and it was found that $124 \mathrm{Gg}$ of methane was released in 2000 [49]. However, the value recalculated using the method and data described above was only $67 \mathrm{Gg}$. This suggests that the original value was an overestimate that implied that the MSW sector should be given more priority than should have been the case. It was reported that solid waste disposed of on land contributed $11.6 \%$ of second national communication $\mathrm{CO}_{2} \mathrm{e}$ emissions, but in fact the value was $6.2 \%$, making the contribution slightly lower than the contribution from the transport sector (6.7\%) [49]. These results suggest that $\mathrm{CO}_{2}$ e emissions from landfills in 2016 contributed $3737 \mathrm{Gg}$ using the revised IPCC 1996 method and $660 \mathrm{Gg} \mathrm{CO}_{2}$ e using the IPCC 2006 method, using a global warming potential of 28 for methane [77]. The methane emissions predictions were more sensitive to the amount of waste produced per capita than to the other variables, but the DOC of the MSW also strongly affected the predicted values. The IPCC 2006 method predicted methane emissions of between 22 and $63 \mathrm{Gg}$ (mean $40 \mathrm{Gg}$ ) in 
2030 and a mean annual increase of $2.6 \%$ (Figure 11). The higher emissions value was $186 \%$ of the lower emissions value, and this would clearly be important when deciding which WtE technologies to use in Bahrain to mitigate climate change.

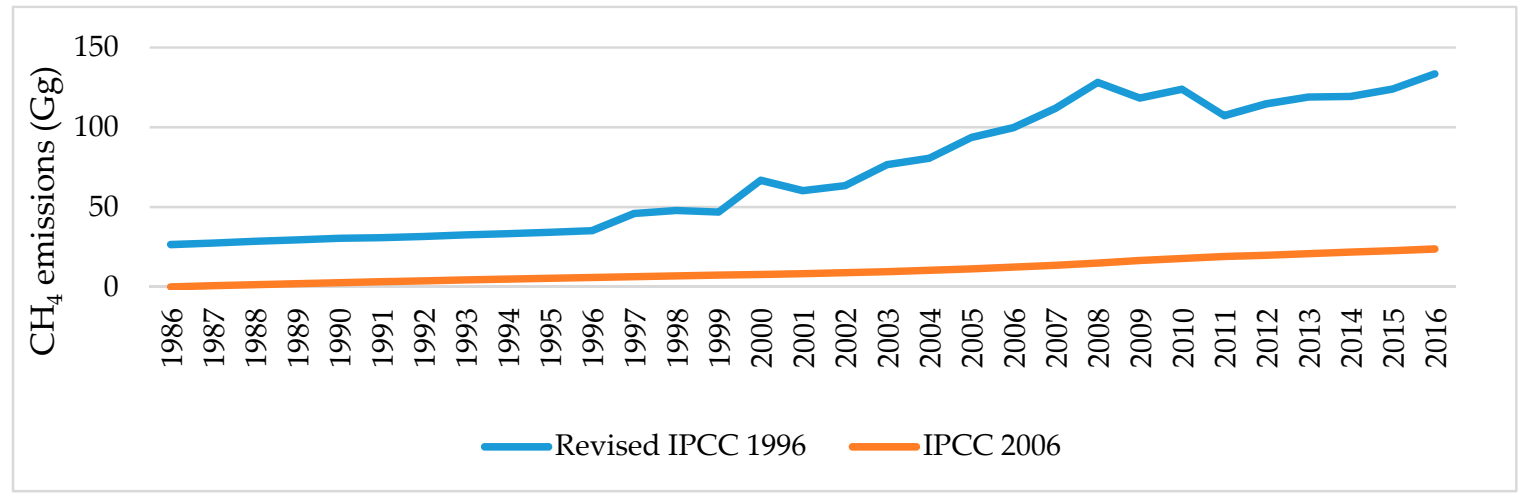

Figure 10. Methane emissions from the Asker landfill between 1986 and 2016, calculated using the revised IPCC 1996 and IPCC 2006 methods.

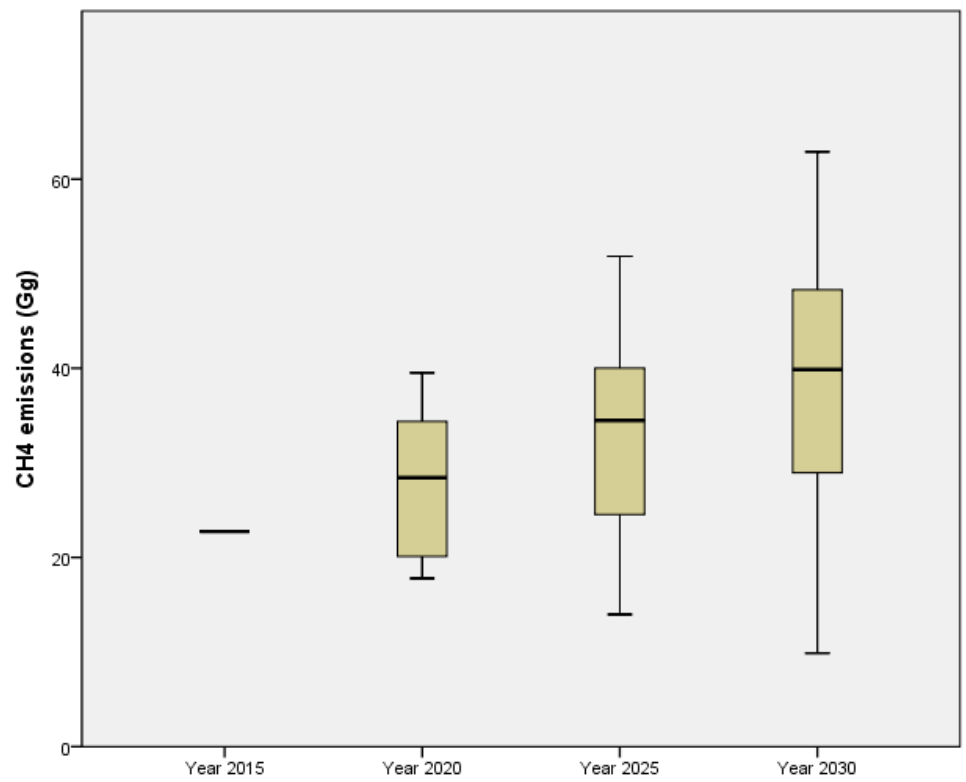

Figure 11. Box plot of methane emissions from the Asker landfill predicted using various degradable organic carbon content (DOC) values, per capita MSW generation rates, and population projections using the IPCC 2006 method.

\subsection{Assessing Various WtE Technologiess in Terms of Effectiveness and Appropriateness for Use in Bahrain}

The calculated energy content of MSW in Bahrain was $\sim 10.6 \mathrm{MJ} / \mathrm{kg}$, which is almost similar to the energy contents of MSW in other GCC countries (Figure 12).

Incineration was found to have the highest electricity generation potential, followed by gasification, $\mathrm{AD}$, and landfill gas recovery (Figure 13). The predicted electricity generation potential for incineration in 2030 was $\sim 1120 \mathrm{MWh} /$ day. The predicted electricity generation potential for landfill gas recovery in 2030 was only $255 \mathrm{MWh} /$ day. These results roughly indicate the amount of electricity that could be generated from MSW but would otherwise be wasted. The sensitivity analyses indicated that incineration would give the most variable electricity generation potential, implying that changing the amount of waste produced per capita, MSW DOC, waste characteristics, or process efficiency would markedly affect the amount of electricity generated, potentially making the amount generated 
as low as the amount that could be generated using other WtE technologies (Figure 14). These data are rough estimates of the potential electricity generation values in use by decision-makers comparing the benefits and costs of $\mathrm{CO}_{2}$ e mitigation measures for different sectors. The generation of electricity from MSW contributes to climate change mitigation through the elimination of landfill gas and replacing fossil fuel-fired power plants [79].

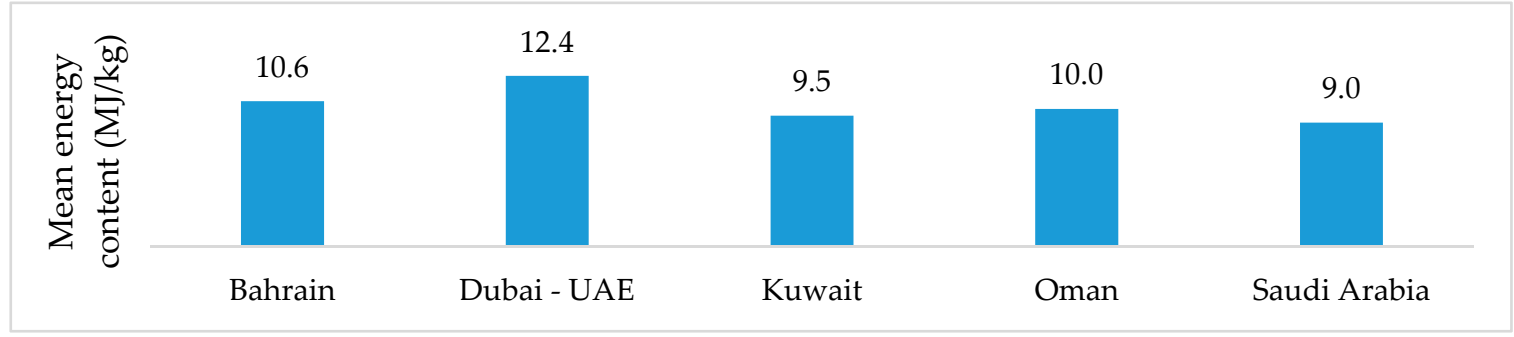

Figure 12. Mean energy contents of municipal solid waste in some Gulf Cooperation Council countries $[26,38,56,57,78]$. Note: the value for Bahrain was calculated in this study. The value for Dubai was calculated after organic waste had been removed to improve energy recovery.

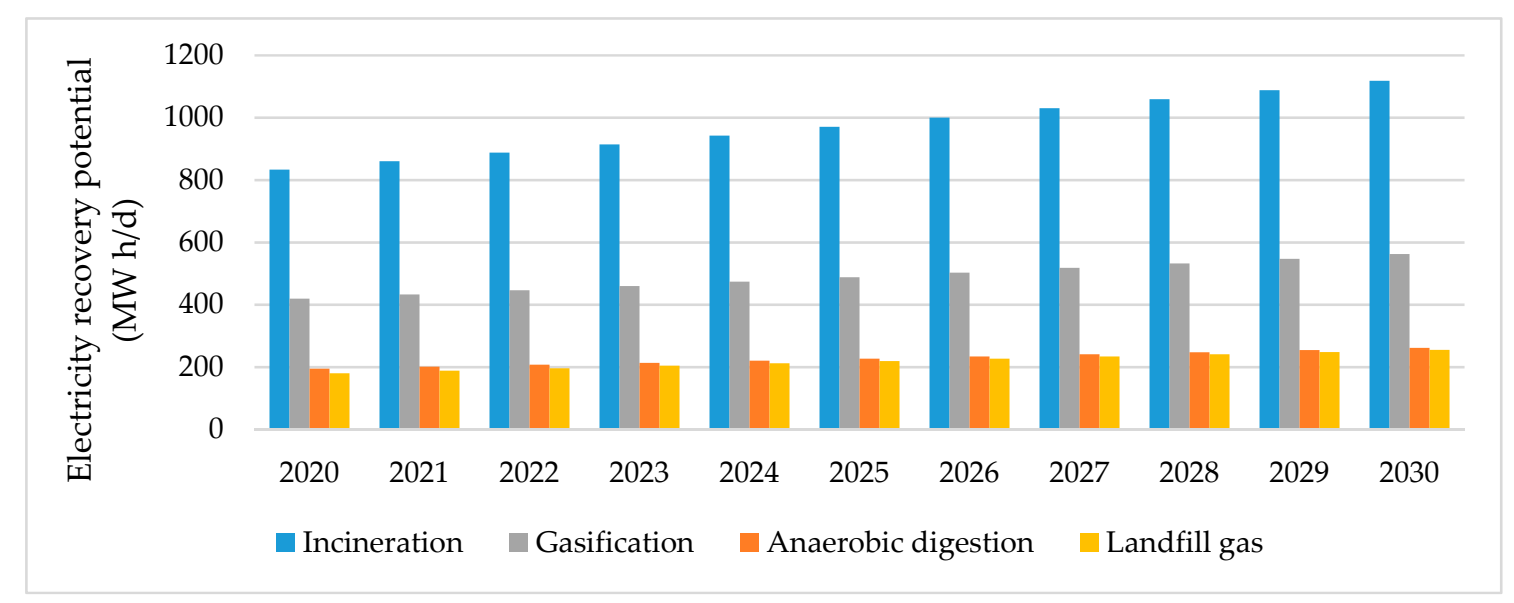

Figure 13. Electricity generation potentials for waste-to-energy technologies in Bahrain between 2020 and 2030.

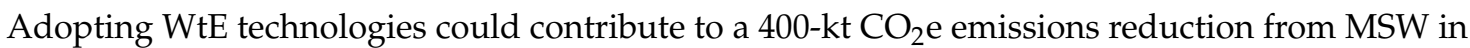
Bahrain in 2030 (Figure 15). The best WtE technology in terms of climate change mitigation is AD, with a potential for emissions reduction ranging between 0.2 and $0.41 \mathrm{tCO}_{2} \mathrm{e}$ per tonne of MSW [6,70].

Incineration has the highest capital, operating, and maintenance costs, and gasification the next highest (Table 4). The total annual costs, including capital, operating, and maintenance costs, for the different WtE technologies were found to be 2-330 USD/t of MSW (Table 4). Potential revenues from the electricity generated would decrease the total cost by 3-47 USD/t of MSW (Table 4). Recovering landfill gas could be profitable, but the capital costs of incineration (in particular) and gasification would remain relatively high, indicating that funding would be required for such projects. 


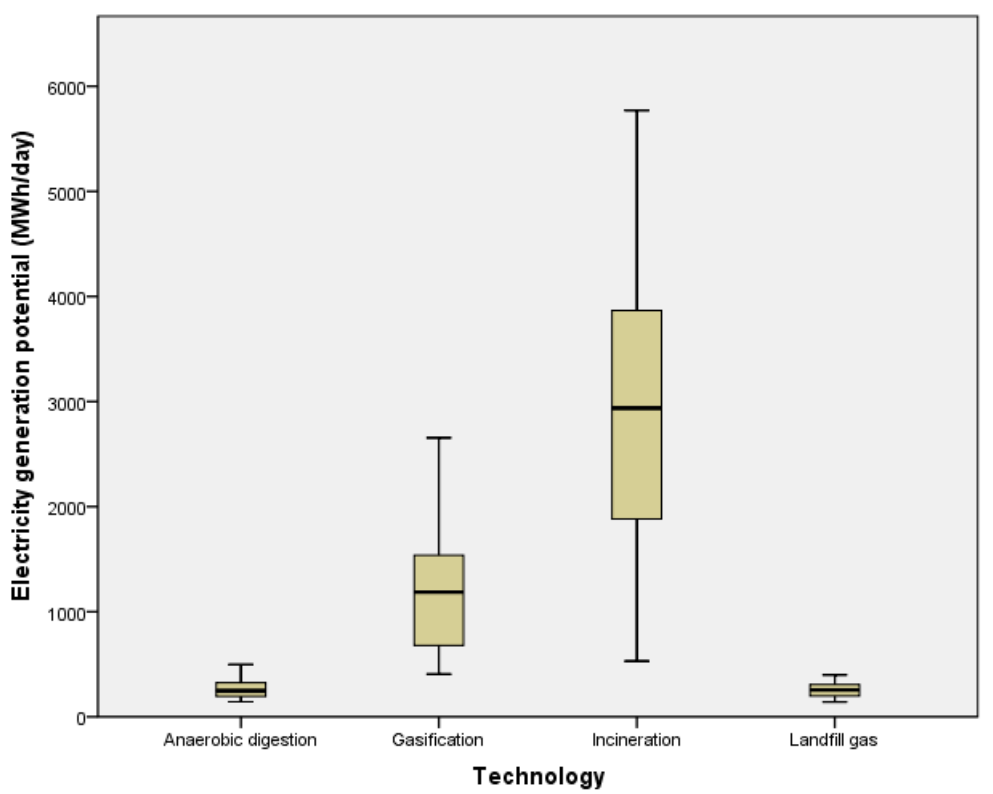

Figure 14. Electricity generation potentials for waste-to-energy technologies in Bahrain in 2030 calculated using various assumptions.

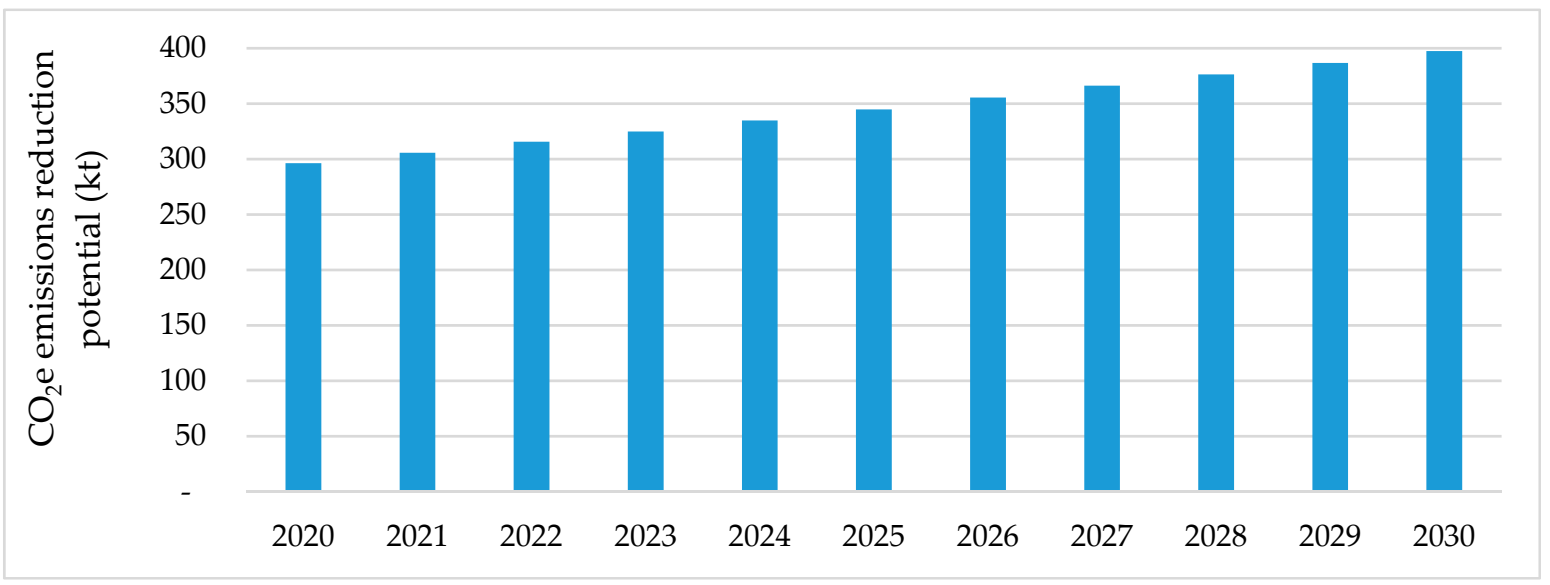

Figure 15. $\mathrm{CO}_{2} \mathrm{e}$ emissions reduction potential from municipal solid waste in Bahrain.

Table 4. Estimated costs of using various waste-to-energy technologies (modified from Reference [14]).

\begin{tabular}{cccccccc}
\hline Technology & $\begin{array}{c}\text { Capital } \\
\text { Cost } \\
\text { (Million } \\
\text { USD) }\end{array}$ & $\begin{array}{c}\text { Annual } \\
\text { Capital } \\
\text { Cost } \\
\text { (USD/t) }\end{array}$ & $\begin{array}{c}\text { Annual } \\
\text { Operating } \\
\text { and } \\
\text { Maintenance } \\
\text { Costs (USD/t) }\end{array}$ & $\begin{array}{c}\text { Total } \\
\text { Annual } \\
\text { Cost } \\
\text { (USD/t) }\end{array}$ & $\begin{array}{c}\text { Plant Size } \\
\text { (kt/year) }\end{array}$ & $\begin{array}{c}\text { Revenue } \\
\text { from } \\
\text { Generating } \\
\text { Electricity } \\
\text { (US } \$ / \text { t) }\end{array}$ & $\begin{array}{c}\text { Total Annual } \\
\text { Cost to Be } \\
\text { Recovered } \\
\text { (US\$/t Waste } \\
\text { Input) }\end{array}$ \\
\hline $\begin{array}{c}\text { Incineration } \\
\text { Anaerobic digestion }\end{array}$ & $151-207$ & $90-129$ & 201 & $291-330$ & 150 & 47 & $244-283$ \\
Landfill gas & $13-22$ & $13-21$ & $11-17$ & $24-38$ & $50-150$ & 5 & $19-33$ \\
Gasification & $60-134$ & $39-50$ & $34-45$ & $73-95$ & 250 & 30 & -1.2 \\
\hline
\end{tabular}

Note: A new sanitary landfill almost the same size as the current landfill (seven cells, each $\sim 60,000 \mathrm{~m}^{2}$ and $4 \mathrm{~m}$ deep, with a total volume for all seven cells of $\sim 1.68 \times 10^{6} \mathrm{~m}^{3}$ ) would cost $\sim 15.2 \times 10^{6} \mathrm{USD}$, based on a construction cost of $\sim 9 \mathrm{USD} / \mathrm{m}^{3}$ [80]. However, the cost of constructing a $2.7 \times 10^{6} \mathrm{~m}^{3}$ cell in a sanitary landfill in Saudi Arabia was only $\sim 5 \times 10^{6}$ USD [81].

Four MCA models were built using the linear additive model and a simple MCA matrix method. These models differed in the assessment criteria and criteria weights (see Section 3.2). The amounts 
of energy recovered, costs, and performances of the different WtE technologies based on selected assessment criteria were aggregated in the four MCA models. The first MCA model indicated that $\mathrm{AD}$ was the most appropriate $\mathrm{WtE}$ technology, with incineration and landfill gas recovery next and gasification the least appropriate (Table 5). AD had high scores for most criteria but requires waste to be segregated and biogas to be treated before use. In contrast, incineration does not require waste to be segregated but does require a constant and stable supply of waste with a high calorific value (Table 1). The second MCA model, using criteria weightings derived from Reference [38], gave almost the same ranking order for the WtE technologies (Equations (13) and (14)). Equation (13) is an example equation for solving the second multiple criteria analysis model. The results of the second multiple criteria analysis model for the use of waste-to-energy technologies in Bahrain are presented in Equation (14).

$$
\begin{aligned}
& \left(\begin{array}{cccc}
\text { Incineration } & 1.00 & 0.50 & 1.00 \\
\text { Anaerobic digestion } & 0.50 & 1.00 & 0.50 \\
\text { Landfill Gas } & 0.25 & 0.25 & 1.00 \\
\text { Gasification } & 0.75 & 0.75 & 0.25
\end{array}\right)\left(\begin{array}{ccc}
\text { Electricity recovery potential } & \text { CO2e emissions } & \text { Impact of inadequate waste segregation } \\
0.25 & 0.50 & 0.25
\end{array}\right)=\left(\begin{array}{l}
0.75 \\
0.75 \\
0.44 \\
0.63
\end{array}\right) \\
& \left(\begin{array}{ccccc}
\text { Incineration } & 0.75 & 0.25 & 0.25 & 1.00 \\
\text { Anaerobic digestion } & 0.75 & 0.75 & 1.00 & 0.75 \\
\text { Landfill Gas } & 0.44 & 1.00 & 1.00 & 0.63 \\
\text { Gasification } & 0.63 & 0.50 & 0.50 & 0.50
\end{array}\right)\left(\begin{array}{l}
0.45 \\
0.31 \\
0.05 \\
0.19
\end{array}\right)=\left(\begin{array}{l}
0.62 \\
0.76 \\
0.68 \\
0.56
\end{array}\right)
\end{aligned}
$$


Table 5. Simple multiple criteria analysis performance matrix for the waste-to-energy technologies.

\begin{tabular}{|c|c|c|c|c|c|c|c|c|c|}
\hline \multirow[b]{2}{*}{ Technology/Criteria } & \multicolumn{3}{|c|}{ Environmental } & \multirow{2}{*}{$\begin{array}{c}\text { Economic } \\
\text { Capital Cost }^{1}\end{array}$} & \multirow{2}{*}{$\begin{array}{c}\text { Social } \\
\begin{array}{c}\text { Public } \\
\text { Acceptance }^{3}\end{array}\end{array}$} & \multicolumn{2}{|c|}{ Other } & \multirow{2}{*}{ Total Score } & \multirow{2}{*}{ Final Rank } \\
\hline & $\begin{array}{l}\text { Electricity Recovery } \\
\text { Potential }^{1}\end{array}$ & $\mathrm{CO}_{2} \mathrm{e} \underset{2}{\text { Emissions }}$ & $\begin{array}{c}\text { Impact of } \\
\text { Inadequate Waste } \\
\text { Segregation }{ }^{2}\end{array}$ & & & Lack of Expertise ${ }^{2}$ & Area Required ${ }^{2}$ & & \\
\hline Incineration & 1 & 0.5 & 1 & 0.25 & 0.25 & 1 & 1 & 5.00 & 2 \\
\hline Anaerobic digestion & 0.5 & 1 & 0.5 & 0.75 & 1 & 1 & 0.5 & 5.25 & 1 \\
\hline Landfill gas & 0.25 & 0.25 & 1 & 1 & 1 & 1 & 0.25 & 4.75 & 3 \\
\hline Gasification & 0.75 & 0.75 & 0.25 & 0.5 & 0.5 & 0.25 & 0.75 & 3.75 & 4 \\
\hline
\end{tabular}

Note: The scale $0-1$ was used, with 1 being the best option, 0.75 the second best option, 0.5 the third best option, and 0.25 the fourth best option. A value of 0 indicates the option is not suitable or recommended. The option with the highest total score is ranked at the top. ${ }^{1}$ Based on Table $4 ;{ }^{2}$ Reference [70]; ${ }^{3}$ Reference [38]. 
The third and fourth MCA models were based on Reference [14], in which a system for selecting WtE technologies for use in developing and emerging countries using 12 criteria was presented. The ranking orders were different from the ranking orders for the first two models. Recovering landfill gas was ranked top, then $\mathrm{AD}$ and incineration, and finally gasification (Table 6). These results appeared to be reasonable because $\mathrm{WtE}$ technologies have not previously been used in Bahrain, so starting with the cheapest option (even though it has a relatively low energy recovery potential) would be sensible now or in the near future once the national waste management strategy has been fully implemented. The results of the four MCA models were aggregated, and the Friedman nonparametric test suggested that there were no statistically significant differences in the ranking orders for the WtE technologies. $\mathrm{AD}$ and landfill gas recovery were ranked highest, then incineration, and finally gasification (Table 7). These results were consistent with the results of previous studies for Saudi Arabia and Oman, for which $\mathrm{AD}$ was also ranked top $[38,43]$.

Table 6. Simple performance matrix for waste-to-energy technologies based on a previous publication [14].

\begin{tabular}{|c|c|c|c|c|c|}
\hline No. & Criterion & Incineration & $\begin{array}{l}\text { Anaerobic } \\
\text { Digestion }\end{array}$ & $\begin{array}{l}\text { Landfill } \\
\text { Gas }\end{array}$ & Gasification \\
\hline $1^{*}$ & $\begin{array}{l}\text { A systematic waste collection is in place; however, recycling is } \\
\text { not organized. }\end{array}$ & 0.75 & 0 & 1 & 0 \\
\hline $1 * *$ & $\begin{array}{l}\text { A systematic waste collection is in place, and recycling } \\
\text { is organized. }\end{array}$ & 1 & 1 & 1 & 0.25 \\
\hline 2 & $\begin{array}{l}\text { MSW is sometimes mixed with fractions of mineral or } \\
\text { hazardous waste. }\end{array}$ & 1 & 0.5 & 1 & 0.5 \\
\hline $3 *$ & Calorific value of the waste is $>8 \mathrm{MJ} / \mathrm{kg}$ on average. & 1 & 1 & 1 & 1 \\
\hline $3 * *$ & $\begin{array}{l}\text { Calorific value of the waste is }<7 \mathrm{MJ} / \mathrm{kg} \text { on average with relatively } \\
\text { high humidity (after removing the plastic waste, assuming the } \\
\text { recycling of it). }\end{array}$ & 0.5 & 1 & 1 & 0 \\
\hline 4 & More than $150 \mathrm{kt} / \mathrm{y}$ of suitable waste is available. & 1 & 1 & 1 & 0.25 \\
\hline $5 *$ & The public/the private sectors have no experience with WtE. & 0 & 0 & 0.75 & 0 \\
\hline $5^{* *}$ & $\begin{array}{l}\text { The public/the private sectors have experience but need } \\
\text { capacity building. }\end{array}$ & 0.75 & 0.75 & 1 & 0.75 \\
\hline 6 & $\begin{array}{l}\text { Almost no changes will occur to the distance/time of } \\
\text { transporting waste. }\end{array}$ & 1 & 1 & 1 & 0.25 \\
\hline 7 & $\begin{array}{l}\text { There is no market for process residues; however, it can be safely } \\
\text { disposed of at a near controlled landfill. }\end{array}$ & 0.75 & 0.75 & 1 & 0.75 \\
\hline 8 & $\begin{array}{l}\text { A national legal framework for WtE exists, and the international } \\
\text { standards are ensured. }\end{array}$ & 0 & 0.75 & 0.75 & 0 \\
\hline 9 & $\begin{array}{l}\text { Costs of waste collection and disposal are covered; however, } \\
\text { covering the cost of } \mathrm{WtE} \text { projects may be difficult. }\end{array}$ & 0.75 & 0.75 & 0.75 & 0.75 \\
\hline 10 & $\begin{array}{l}\text { Most spare parts can be purchased locally, and sale offices for } \\
\text { imported spare parts are also available. }\end{array}$ & 0.75 & 0.75 & 1 & 0.75 \\
\hline 11 & $\begin{array}{l}\text { WtE facilities are close to end users, and good transport } \\
\text { infrastructure exists. }\end{array}$ & 1 & 1 & 1 & 0.25 \\
\hline 12 & $\begin{array}{l}\text { Economic incentives for low carbon energy generation are } \\
\text { regulated by law but may not have been implemented yet. }\end{array}$ & 0.75 & 0.75 & 1 & 0.75 \\
\hline & Total score (current state) & 8.75 & 8.25 & 11.25 & 5.25 \\
\hline & Final rank & 2 & 2 & 1 & 4 \\
\hline & Total score (near future) & 9.25 & 10 & 11.5 & 5.25 \\
\hline & Final rank & 3 & 2 & 1 & 4 \\
\hline
\end{tabular}

Note: The scale $0-1$ was used, with 1 being the best option, 0.75 the second best option, 0.5 the third best option, and 0.25 the fourth best option. A value of 0 indicates the option is not suitable or recommended. The option with the highest total score is ranked at the top. ${ }^{*}$ The current state; ${ }^{* *}$ the state in the near future. 
Table 7. Rankings of the waste-to-energy (WtE) technologies for Bahrain, determined using the four multicriteria analysis (MCA) models.

\begin{tabular}{ccccc}
\hline WtE Technology & $\begin{array}{c}\text { First MCA } \\
\text { Model }\end{array}$ & $\begin{array}{c}\text { Second MCA } \\
\text { Model }\end{array}$ & $\begin{array}{c}\text { Third MCA } \\
\text { Model }\end{array}$ & $\begin{array}{c}\text { Fourth MCA } \\
\text { Model }\end{array}$ \\
\hline Incineration & 2 & 3 & 2 & 3 \\
Anaerobic & 1 & 1 & 2 & 2 \\
digestion & 3 & 2 & 1 & 1 \\
Landfill gas & 4 & 4 & 4 & 4 \\
Gasification & &
\end{tabular}

Comparing the WtE technologies by performing MCAs allowed for several quantitative and qualitative assessment criteria to be taken into consideration. The assessment criteria selected strongly affected the ranking order. Ensuring that all of the relevant criteria were selected was therefore important to assessing the performances, strengths, and weaknesses of WtE technologies. However, selecting the most appropriate $\mathrm{WtE}$ technology is not easy, because it is important to minimize negative impacts on the environment [38].

There are several challenges to the use of WtE in Bahrain. The first is the energy content and composition of MSW. Waste with a high moisture content, e.g., food waste, can negatively affect incineration and gasification by causing the energy recovery potential to be low $[21,22,71]$. MSW with a lower heating value (LHV) of less than $3.15 \mathrm{MJ} / \mathrm{kg}$ can give very low electricity generation efficiencies for incinerators (mean 22\%), and some of the electricity generated will be consumed by certain processes within an incinerator. This means that if most paper and plastic waste in Bahrain is recycled, the electricity generation potential of MSW could be low [82]. This is because plastic waste and paper waste are good fuels for WtE incinerators [14,21]. This means that all waste recycling plans must be considered before deciding whether MSW should be incinerated.

The second challenge is related to waste production being stable enough to ensure energy can be recovered effectively. Waste production stability is perceived to be a barrier in many countries [71]. There is an alarming trend in Bahrain. The total amount of waste produced in the Capital Governorate decreased by $23 \%$ in the first quarter of 2019 . This could have been caused by waste awareness campaigns or the implementation of a new value-added tariff. This decrease in MSW production will affect the cost effectiveness and energy recovery potential of WtE technologies. Other factors could also affect the waste production stability. For example, campaigns to distribute food waste and campaigns to decrease plastic use could affect MSW production stability. All future campaigns and changes in reuse and recycling activities must be considered when planning the use of WtE technologies in Bahrain.

Another potential challenge is controlling air pollution and ensuring that toxic flue gases (e.g., polychlorinated dibenzo- $p$-dioxins and dibenzofurans) are removed [22,71]. This is not an issue in the EU because of strict laws and the use of advanced technologies. Polychlorinated dibenzo- $p$-dioxin, dibenzofuran, and particulate matter $\left(\mathrm{PM}_{10}\right)$ emissions during $\mathrm{WtE}$ incineration are minimal in the $\mathrm{EU}$ in both absolute terms and in terms of the contributions of such emissions to total emissions [83]. Although flue gas emissions for the best available technologies are low, they are close to flue gas emissions limits in the EU [17]. Complying with strict emissions limits increases construction costs [83]. Emissions during incineration are not controlled effectively in many developing countries because of the high costs involved [7].

The cost of investing in $\mathrm{WtE}$ technologies is relatively high compared to the costs involved in conventional and renewable energy sources. WtE technologies have been estimated to cost 1700-2000 USD/kW to install, whereas natural gas combined cycle systems cost 450-1500 USD/kW to install, photovoltaic systems are 900-1500 USD/kW to install, and onshore wind turbines are 1100-1500 USD/kW to install [84]. The capital cost may be perceived to be an obstacle in Bahrain, particularly because a "fiscal balance program" has been implemented for 2019-2022. The annual budget for projects was $530 \times 10^{6}$ USD in the recently approved state budget for the fiscal years 2019-2020. 
Previously published capital costs have ranged from $6 \times 10^{6}$ to $207 \times 10^{6}$ USD (Table 4), but the actual costs for similar projects in other GCC countries have been much higher (Table 2) and have been close to or higher than the annual budget for projects in Bahrain. Establishing similar projects in Bahrain in this period will therefore need to be strongly justified, if such a project is to be financed by the government, to ensure that the three pillars of sustainable development (society, economy, and environment) are considered.

There are two main justifications for financing WtE projects in Bahrain: to contribute to achieving the renewable energy targets of $5 \%$ by 2025 and $10 \%$ by 2035 or to decrease $\mathrm{CO}_{2}$ e emissions. The capital costs of other types of renewable energy in Bahrain range from $11 \times 10^{6}$ USD for offshore wind to $115 \times 10^{6}$ USD for solar energy. WtE technologies cost considerably more. The electricity generation potentials for WtE technologies in Bahrain are very sensitive to several factors, making it difficult to guarantee the generation of large amounts of electricity. WtE incinerators have the highest electricity generation potential, but the capacity of $\mathrm{WtE}$ incinerators would be $\sim 100 \mathrm{MW}$, which is only $14 \%$ of the renewable energy goal, and the cost would be higher than, for example, solar energy. In terms of using WtE technologies to decrease $\mathrm{CO}_{2} \mathrm{e}$ emissions, the share the waste sector could contribute to decreasing total national emissions will be relatively low, making it logical to target emissions from other sectors.

One last justification for using WtE technologies could be valid. This is decreasing the area required for landfills if current economic, social, and environmental conditions are assumed to be valid in the future. Bahrain has limited areas available for landfills, so it would be wise to decrease the area required for MSW. However, there may be other ways of achieving this, such as by exporting MSW to neighboring countries with WtE plants but insufficient MSW. Nonetheless, there are several international funding opportunities for developing WtE plants, including the "Green Climate Fund" and the "Nationally Appropriate Mitigation Actions (NAMA) facility" [73].

Despite the challenges, it is imperative to ensure public participation throughout a WtE project to ensure success [17]. Public approval must be obtained before construction of a WtE plant because of environmental concerns. Public objections to WtE plants have caused many projects around the world to be terminated or delayed [45].

The challenges to establishing WtE plants (described above) have been addressed in many studies performed worldwide. In general, WtE technologies are supported in many developing countries, but there is a growing trend against incineration in some developed countries. For example, some nongovernmental organizations in the EU have argued that incineration closes the material loop and does not encourage recycling. The European Commission has suggested that the waste hierarchy should be used as a guideline and that an incineration plant should not be constructed unless there is a guaranteed feedstock for the lifetime of the plant, taking recycling obligations into consideration. On the other hand, some people perceive waste to be a source of renewable energy that can help countries meet their renewable energy goals [85].

The findings of this paper suggest several policy implications for Bahrain, as follows:

- Although the national waste strategy suggests that Estidama is responsible for data collection, it is imperative to provide data and indicators related to waste in Bahrain. Such data are not only missing in Bahrain but also in some other countries in the GCC [40];

- Set targets for waste recycling and WtE and ensure collaboration with stakeholders;

- Ensure consistency in waste-relevant policies among different stakeholders;

- Encourage the reduction, reuse, and recycling of waste before disposal, which contributes to climate change mitigation;

- Emphasize the need to adopt a participatory approach to waste management in Bahrain.

It is recommended for Bahrain and perhaps for other areas with similar circumstances that an understanding of how the fiscal balance program influences the quantity and characteristics of MSW be gained before decisions about establishing WtE plants are made. It is recommended that Bahrain wait until 2021 to make such decisions because WtE plants in other GCC countries will start operating 
at that time. This will allow the performances of those plants to be assessed and the energy recovery potentials in the ex ante assessments to be compared to the actual electricity production values in ex post assessments.

\section{Conclusions}

In this paper, historical $\mathrm{CO}_{2} \mathrm{e}$ emissions from MSW in Bahrain were calculated, future emissions were predicted, and the effectiveness of several $\mathrm{WtE}$ technologies was assessed as a means for climate change mitigation. The originality of this paper lies in presenting a new case study for which new data were provided, especially concerning $\mathrm{CO}_{2} \mathrm{e}$ emissions and energy recovery potential. The details of the case of Bahrain were explored and synthesized for the first time, giving insights into a previously unexplored sector for climate change mitigation in Bahrain. Additionally, a set of existing methods was used in an integrated way to give a holistic picture of the waste sector in Bahrain and how it contributes to climate change. The integrated approach to the assessment of WtE technologies provided insights into the performance of each technology against selected assessment criteria. Furthermore, developing multiple MCA models showed the robustness of the results and how the ranking order of the technologies changed only slightly when different criteria and criteria weights were used. However, the adopted approach had some limitations. The limitations included subjectivity in the selection of criteria and criteria weights, in addition to the validity of assumptions used in the assessment. These limitations can be overcome with proper research design.

Although this study focused on Bahrain, several lessons can be drawn from the findings for application in other developing countries, including:

- Considering the three pillars of sustainability to balance decision-making between the environment, economy, and society;

- Considering a group of factors before adopting any of the WtE technologies. These include energy costs, MSW composition, waste production stability, air pollution control, investment costs, and public participation and acceptance;

- Bearing in mind that potential energy recovery is sensitive to many factors, and if energy recovery is emphasized, then the WtE technologies need to carefully be assessed;

- Ensuring integration of the policies in different sectors, as policies and targets in one sector may support WtE technologies (e.g., waste management and renewable energy targets), while policies in another sector contradict them (e.g., plastic waste minimization plans, which reduce the electricity generation potential);

- Solutions beyond the geographical space may exist, such as transporting waste to a neighboring country, especially if part of an economic union and the WtE plants in the other country lack sufficiently large quantities of waste.

The results of this paper led to four main recommendations, given below:

- Ensure integration in terms of planning for different sectors. Mitigating $\mathrm{CO}_{2} \mathrm{e}$ emissions from waste is linked to climate change mitigation, environmental management, and energy planning;

- Capacity building for WtE technologies needs to be increased, and technologies may need to be modified to meet local needs;

- Encourage performance assessments of WtE technologies in different countries to be reported. This could form part of the north-south collaboration within the Paris Agreement. Accessible databases for WtE plants around the world should be made available;

- Create links between GCC countries related to WtE technologies to allow experiences and success stories to be shared and to inform decision-makers.

Future research should be focused on maximizing the benefits of WtE technologies to make them attractive to petroleum-producing countries and competitive with renewable and nonrenewable energy 
sources. Research focused on decreasing $\mathrm{CO}_{2} \mathrm{e}$ emissions from MSW in GCC countries using other mitigation measures should also be explored.

Funding: This research was funded by the Arabian Gulf University, grant number NR-AK-2017.

Conflicts of Interest: The funder had no role in the design of the study; in the collection, analyses, or interpretation of data; in the writing of the manuscript; or in the decision to publish the results.

\section{References}

1. IEA/OECD. Key World Energy Statistics; IEA: Paris, France, 2018.

2. Sabouni, R.; Blaschke, C.; Bkayrat, R.; Gentil, S. Energy Efficiency in the GCC: Status and Outlook. Available online: http://cebcmena.com/wp-content/uploads/2018/03/CEBC-Energy-Efficiency-in-the-GCC-January2018-REV2.pdf (accessed on 21 July 2019).

3. IRENA. Renewable Energy: Market. Analysis; IRENA: Abu Dhabi, UAE, 2019.

4. Wogan, D.; Pradhan, S.; Albardi, S. GCC Energy System: Overview—2017; KAPSARC: Riad, Saudi Arabien, 2017.

5. Bogner, J.; Ahmed, M.; Diaz, C.; Faaij, A.; Gao, Q.; Hashimoto, S.; Mareckova, K.; Pipatti, R.; Zhang, T. Waste management. In Climate Change 2007: Mitigation. Contribution of Working Group III to the Fourth Assessment Report of the Intergovernmental Panel on Climate Change; Metz, B., Davidson, O.R., Bosch, P.R., Dave, R., Meyer, L.A., Eds.; Cambridge University Press: Cambridge, UK; New York, NY, USA, 2007.

6. Fischedick, M.; Roy, J.; Abdel-Aziz, A.; Acquaye, A.; Allwood, J.M.; Ceron, J.P.; Geng, Y.; Kheshgi, H.; Lanza, A.; Perczyk, D.; et al. Industry. In Climate Change 2014: Mitigation of Climate Change. Contribution of Working Group III to the Fifth Assessment Report of the Intergovernmental Panel on Climate Change; Edenhofer, O., Pichs-Madruga, R., Sokona, Y., Farahani, E., Kadner, S., Seyboth, K., Adler, A., Baum, I., Brunner, S., Eickemeier, P., et al., Eds.; Cambridge University Press: Cambridge, UK; New York, NY, USA, 2014.

7. Bogner, J.; Pipatti, R.; Hashimoto, S.; Diaz, C.; Mareckova, K.; Diaz, L.; Kjeldsen, P.; Monni, S.; Faaij, A.; Gao, Q.; et al. Mitigation of global greenhouse gas emissions from waste: Conclusions and strategies from the Intergovernmental Panel on Climate Change (IPCC) Fourth Assessment Report. Working Group III (Mitigation). Waste management \& research. J. Int. Solid Wastes Public Clean. Assoc. ISWA 2008, 26, 11-32. [CrossRef]

8. Hoa, N.T.; Matsuoka, Y. The analysis of greenhouse gas emissions/reductions in waste sector in Vietnam. Mitig. Adapt. Strateg. Glob. Chang. 2017, 22, 427-446. [CrossRef]

9. Pikoń, K.; Gaska, K. Greenhouse gas emission mitigation relevant to changes in municipal solid waste management system. J. Air Waste Manag. Assoc. 2012, 60, 782-788. [CrossRef]

10. Chandel, M.K.; Kwok, G.; Jackson, R.B.; Pratson, L.F. The potential of waste-to-energy in reducing GHG emissions. Carbon Manag. 2012, 3, 133-144. [CrossRef]

11. Mustafa, S.S.; Mustafa, S.S.; Mutlag, A.H. Kirkuk municipal waste to electrical energy. Int. J. Electr. Power Energy Syst. 2013, 44, 506-513. [CrossRef]

12. Kawai, K.; Tasaki, T. Revisiting estimates of municipal solid waste generation per capita and their reliability. J. Mater. Cycles Waste Manag. 2015, 18, 1-13. [CrossRef]

13. Ecoprog. Waste-to-Energy 2018/2019. Available online: https://www.ecoprog.com/publications/energymanagement/waste-to-energy.htm (accessed on 28 May 2019).

14. Mutz, D.; Hengevoss, D.; Hugi, C.; Gross, T. Waste-to-Energy Options in Municipal Solid Waste Management; GIZ: Eschborn, Germany, 2017.

15. Alzate, S.; Restrepo-Cuestas, B.; Jaramillo-Duque, Á. Municipal solid waste as a source of electric power generation in Colombia: A techno-economic evaluation under different scenarios. Resources 2019, 8, 51. [CrossRef]

16. Council, W.E. World Energy Resources: Waste to Energy. Available online: https://www.worldenergy.org/ wp-content/uploads/2016/10/World-Energy-Resources-Full-report-2016.10.03.pdf (accessed on 28 May 2019).

17. ISWA. ISWA Guidelines: Waste to Energy in Low and Middle Income Countries; ISWA: Vienna, Austria, 2013.

18. Makarichi, L.; Jutidamrongphan, W.; Techato, K.A. The evolution of waste-to-energy incineration: A review. Renew. Sustain. Energy Rev. 2018, 91, 812-821. [CrossRef] 
19. Alzate Arias, S.; Restrepo-Cuestas, B.; Jaramillo-Duque, Á. Electricity generation potential from solid waste in three Colombian municipalities. TecnoLógicas 2018, 21, 111-128. [CrossRef]

20. Carneiro, M.L.N.M.; Gomes, M.S.P. Energy, exergy, environmental and economic analysis of hybrid waste-to-energy plants. Energy Convers. Manag. 2019, 179, 397-417. [CrossRef]

21. Chen, Y.C. Evaluating greenhouse gas emissions and energy recovery from municipal and industrial solid waste using waste-to-energy technology. J. Clean. Prod. 2018, 192, 262-269. [CrossRef]

22. Alzate-Arias, S.; Jaramillo-Duque, Á.; Villada, F.; Restrepo-Cuestas, B. Assessment of government incentives for energy from waste in Colombia. Sustainability 2018, 10, 1294. [CrossRef]

23. Abushammala, M.F.; Qazi, W.A.; Azam, M.H.; Mehmood, U.A.; Al-Mufragi, G.A.; Alrawahi, N.A. Economic and environmental benefits of landfill gas utilisation in Oman. Waste Manag. Res. J. Int. Solid Wastes Public Clean. Assoc. ISWA 2016, 34, 717-723. [CrossRef]

24. Abdallah, M.; Shanableh, A.; Shabib, A.; Adghim, M. Financial feasibility of waste to energy strategies in the United Arab Emirates. Waste Manag. 2018, 82, 207-219. [CrossRef]

25. Nizami, A.S.; Shahzad, K.; Rehan, M.; Ouda, O.K.M.; Khan, M.Z.; Ismail, I.M.I.; Almeelbi, T.; Basahi, J.M.; Demirbas, A. Developing waste biorefinery in Makkah: A way forward to convert urban waste into renewable energy. Appl. Energy 2017, 186, 189-196. [CrossRef]

26. Ouda, O.K.M.; Cekirge, H.M.; Raza, S.A.R. An assessment of the potential contribution from waste-to-energy facilities to electricity demand in Saudi Arabia. Energy Convers. Manag. 2013, 75, 402-406. [CrossRef]

27. Anshar, M.; Ani, F.; Kader, A. The energy potential of municipal solid waste for power generation in Indonesia. J. Mek. 2014, 37, 42-54.

28. Abdallah, M.; Shanableh, A.; Arab, M.; Shabib, A.; Adghim, M.; El-Sherbiny, R. Waste to energy potential in middle income countries of MENA region based on multi-scenario analysis for Kafr El-Sheikh Governorate, Egypt. J. Environ. Manag. 2019, 232, 58-65. [CrossRef]

29. Fernandez-Gonzalez, J.M.; Grindlay, A.L.; Serrano-Bernardo, F.; Rodriguez-Rojas, M.I.; Zamorano, M. Economic and environmental review of waste-to-energy systems for municipal solid waste management in medium and small municipalities. Waste Manag. 2017, 67, 360-374. [CrossRef]

30. Mambeli Barros, R.; Tiago Filho, G.L.; da Silva, T.R. The electric energy potential of landfill biogas in Brazil. Energy Policy 2014, 65, 150-164. [CrossRef]

31. Cabaraban, M.T.I.; Paclijan, S.S. Estimation of landfill gas production and the energy potential of municipal solid wastes from the upper Dagong dumpsite using the Philippine landfill gas model v.1. WIT Transactions on Ecology and the Environment 2015, 1, 295-301. [CrossRef]

32. Aguilar-Virgen, Q.; Taboada-González, P.; Ojeda-Benítez, S. Analysis of the feasibility of the recovery of landfill gas: A case study of Mexico. J. Clean. Prod. 2014, 79, 53-60. [CrossRef]

33. Johari, A.; Ahmed, S.I.; Hashim, H.; Alkali, H.; Ramli, M. Economic and environmental benefits of landfill gas from municipal solid waste in Malaysia. Renew. Sustain. Energy Rev. 2012, 16, 2907-2912. [CrossRef]

34. Perkoulidis, G.; Kasampalis, T.; Karagiannidis, L.; Moussiopoulos, N. Development of waste-to-energy plants database for evaluating the efficiency of energy recovery from waste in Europe. Waste Biomass Valor. 2015, 6, 983-988. [CrossRef]

35. Al Ahmad, M.; Dimashki, M.; Nassour, A.; Nelles, M. Characterization, concentrations and emission rates of volatile organic compounds from two major landfill sites in Kuwait. Am. J. Environ. Sci. 2012, 8, 56-63.

36. Al-Jarallah, R.; Aleisa, E. A baseline study characterizing the municipal solid waste in the state of Kuwait. Waste Manag. 2014, 34, 952-960. [CrossRef] [PubMed]

37. Koushki, P.A.; Al-Khaleefi, A.L. An analysis of household solid waste in Kuwait: Magnitude, type, and forecasting models. J. Air Waste Manag. Assoc. 1998, 48, 256-263. [CrossRef] [PubMed]

38. Qazi, W.A.; Abushammala, M.F.; Azam, M.H. Multi-criteria decision analysis of waste-to-energy technologies for municipal solid waste management in Sultanate of Oman. Waste Manag. Res. J. Int. Solid Wastes Public Clean. Assoc. ISWA 2018, 36, 594-605. [CrossRef] [PubMed]

39. Aleisa, E.; Al-Jarallah, R.; Shehada, D. The effect of geological and meteorological conditions on municipal waste management systems: A life cycle assessment approach. Int. J. Environ. Sci. Technol. 2019, 16, 485-494. [CrossRef]

40. Lahou, A.A.; Alsabbagh, M. Assessment of municipal solid waste management in the state of Kuwait. Int. J. Environ. Sci. Dev. 2019, 10, 51-56. [CrossRef] 
41. Hadidi, L.A.; Omer, M.M. A financial feasibility model of gasification and anaerobic digestion waste-to-energy (WTE) plants in Saudi Arabia. Waste Manag. 2017, 59, 90-101. [CrossRef] [PubMed]

42. Shahzad, K.; Nizami, A.S.; Sagir, M.; Rehan, M.; Maier, S.; Khan, M.Z.; Ouda, O.K.; Ismail, I.M.; BaFail, A.O. Biodiesel production potential from fat fraction of municipal waste in Makkah. PLoS ONE 2017, 12, e0171297. [CrossRef] [PubMed]

43. Baig, M.B.; Gorski, I.; Neff, R.A. Understanding and addressing waste of food in the Kingdom of Saudi Arabia. Saudi J. Biol. Sci. 2018. [CrossRef]

44. Allesch, A.; Brunner, P.H. Assessment methods for solid waste management: A literature review. Waste Manag. Res. 2014, 32, 461-473. [CrossRef] [PubMed]

45. Cucchiella, F.; D'Adamo, I.; Gastaldi, M. Sustainable waste management: Waste to energy plant as an alternative to landfill. Energy Convers. Manag. 2017, 131, 18-31. [CrossRef]

46. Dong, J.; Tang, Y.; Nzihou, A.; Chi, Y.; Weiss-Hortala, E.; Ni, M.; Zhou, Z. Comparison of waste-to-energy technologies of gasification and incineration using life cycle assessment: Case studies in Finland, France and China. J. Clean. Prod. 2018, 203, 287-300. [CrossRef]

47. Gumisiriza, R.; Hawumba, J.F.; Okure, M.; Hensel, O. Biomass waste-to-energy valorisation technologies: A review case for banana processing in Uganda. Biotechnol. Biofuels 2017, 10, 11. [CrossRef] [PubMed]

48. PMEW. Bahrain's Initial Communications to the United Nations Framework Convention on Climate Change; PMEW: Manama, Bahrain, 2005.

49. PMEW. Bahrain's Second National Communication; PMEW: Manama, Bahrain, 2012.

50. Authority, I.A.E. Statistical Abstract. Available online: http://www.data.gov.bh/en/ResourceCenter (accessed on 28 May 2019).

51. Supreme Council for Environment. Waste Quantity and Type in Bahrain. Unpublished report. 2017.

52. Bank, T.W. GDP (Current US\$). Available online: https://data.worldbank.org/indicator/NY.GDP.MKTP.CD? locations $=\mathrm{BH}$ (accessed on 28 May 2019).

53. Al Sabbagh, M.K.; Velis, C.A.; Wilson, D.C.; Cheeseman, C.R. Resource management performance in Bahrain: A systematic analysis of municipal waste management, secondary material flows and organizational aspects. Waste Manag. Res. J. Int. Solid Wastes Public Clean. Assoc. ISWA 2012, 30, 813-824. [CrossRef] [PubMed]

54. Musaiger, A.; Al Zayani, A. (Eds.) The Environment in Bahrain: The State and Challenges; BCSR: Manama, Bahrain, 2008.

55. Alayam. Minster of Works: 195 Thousand Tonnes of Food Waste Annually. Available online: https: //www.alayam.com/online/local/737712/News.html (accessed on 3 June 2019).

56. Fichtner. Waste Composition and Characterization Study. Unpublished report. 2014.

57. Energy, U.M.O. The UAE State of Energy Report 2015. Available online: https://issuu.com/dccepublications/ docs/soer_2015_book_final_single_low/75 (accessed on 3 June 2019).

58. Gloom, S.; Alyousfi, B.; Aljenaid, S. Solid waste landfills as carbon sinks for sequestration of greenhouse gases and curtailment of climate change phenomenon. Arab Gulf J. Sci. Res. 2014, 32, 192-199.

59. Al-Joburi, K.I. Mapping Bahrain's subsurface municipal solid waste. Arab. J. Geosci. 2018, 11. [CrossRef]

60. Mohareb, E.A.; MacLean, H.L.; Kennedy, C.A. Greenhouse gas emissions from waste management-Assessment of quantification methods. J. Air Waste Manag. Assoc. 2011, 61, 480-493. [CrossRef] [PubMed]

61. IPCC/OECD/IEA. Revised 1996 IPCC Guidelines for National Greenhouse Gas. Inventories: Reference Manual; UK Metrological Office: Bracknell, UK, 1997.

62. Eggleston, H.S.; Buendia, L.; Miwa, K.; Ngara, T.; Tanabe, K. Guidelines for National Greenhouse Gas. Inventories; IGES: Hayama, Japan, 2006.

63. Bank, T.W. Population Estimates And Projections. Available online: https://datacatalog.worldbank.org/ dataset/population-estimates-and-projections (accessed on 29 May 2019).

64. Gómez, A.; Zubizarreta, J.; Rodrigues, M.; Dopazo, C.; Fueyo, N. Potential and cost of electricity generation from human and animal waste in Spain. Renew. Energy 2010, 35, 498-505. [CrossRef]

65. Saarikoski, H.; Mustajoki, J.; Marttunen, M. Participatory multi-criteria assessment as 'opening up' vs. 'closing down' of policy discourses: A case of old-growth forest conflict in Finnish Upper Lapland. Land Use Policy 2013, 32, 329-336. [CrossRef]

66. Government, D.f.C.A.L. Multi-Criteria Analysis: A Manual; Department for Communities and Local Government: London, UK, 2009. 
67. Fulop, J. Introduction to Decision Making Methods. Available online: https://pdfs.semanticscholar.org/e0d8/ d4fd210c4aeae40560c7332711c7cc8dc5df.pdf (accessed on 29 May 2019).

68. Gamper, C.D.; Turcanu, C. On the governmental use of multi-criteria analysis. Ecol. Econ. 2007, 62, $298-307$. [CrossRef]

69. Huang, I.B.; Keisler, J.; Linkov, I. Multi-criteria decision analysis in environmental sciences: Ten years of applications and trends. Sci. Total Environ. 2011, 409, 3578-3594. [CrossRef] [PubMed]

70. Yap, H.Y.; Nixon, J.D. A multi-criteria analysis of options for energy recovery from municipal solid waste in India and the UK. Waste Manag. 2015, 46, 265-277. [CrossRef] [PubMed]

71. Xin-Gang, Z.; Gui-Wu, J.; Ang, L.; Yun, L. Technology, cost, a performance of waste-to-energy incineration industry in China. Renew. Sustain. Energy Rev. 2016, 55, 115-130. [CrossRef]

72. Munster, M.; Lund, H. Comparing waste-to-energy technologies by applying energy system analysis. Waste Manag. 2010, 30, 1251-1263. [CrossRef] [PubMed]

73. UNFCCC. Mitigation Benefits and Co-Benefits of Policies, Practices and Actions for Enhancing Mitigation Ambition: Implementation of Circular Economies with a Focus on Wasteto-Energy Technologies and on Industrial Waste Reuse and Prevention Solutions. Available online: https://unfccc.int/sites/default/files/ resource/tpMitigation.pdf (accessed on 29 May 2019).

74. Gibbons, J. Nonparametric Statistics: An. Introduction; SAGE Publications: Newbury Park, CA, USA, 1992.

75. Jarrell, S. Basic Statistics; Wm. C. Brown Publishers: Oxford, UK, 1994.

76. Kirk, R. Statistics: An Introduction; Harcourt Brace College Publishers: Fort Worth, TX, USA, 1999.

77. IPCC. Climate Change 2014: Synthesis Report. Contribution of Working Groups I, II and III to the Fifth Assessment Report of the Intergovernmental Panel on Climate Change. Available online: https: //www.ipcc.ch/site/assets/uploads/2018/02/SYR_AR5_FINAL_full.pdf (accessed on 29 May 2019).

78. Al-Waked, R.; Ouda, O.; Raza, S. Potential value of waste-to-energy facility in Riyadh City—Saudi Arabia. In Proceedings of the Conference Paper. The 8th Jordanian International Mechanical Engineering Conference, Amman, Jordan, 22-23 September 2014.

79. Michael, T. 2-Environmental and social impacts of waste to energy (WTE) conversion plants. In Waste to Energy Conversion Technology; Klinghoffer, N.B., Castaldi, M.J., Eds.; Woodhead Publishing: Cambridge, UK, 2013; pp. 15-28.

80. Pivato, A.; Masi, S.; De Caprio, D.; Tommasin, A. Sanitary landfill costs from design to aftercare: Criteria for defining unit cost. Detritus 2018, 4, 140. [CrossRef]

81. Bagazi, A. A new landfill in Jeddah with a capacity of 1.5 million tonnes annually. Asharq Al-Awsat 2011.

82. Astrup, T.; Moller, J.; Fruergaard, T. Incineration and co-combustion of waste: Accounting of greenhouse gases and global warming contributions. Waste Manag. Res. J. Int. Solid Wastes Public Clean. Assoc. ISWA 2009, 27, 789-799. [CrossRef] [PubMed]

83. ESWET. Everything You Always Wanted to Know About Waste-to-Energy. Available online: http://www.eswet.eu/tl_files/eswet/5.\%20Documents/5.1.\%20Waste-to-Energy\%20Handbook/ ESWET_Handbook_Waste-to-Energy.pdf (accessed on 30 May 2019).

84. Eveloy, V.; Gebreegziabher, T. Excess electricity and power-to-gas storage potential in the future renewable-based power generation sector in the United Arab Emirates. Energy 2019, 166, 426-450. [CrossRef]

85. Malinauskaite, J.; Jouhara, H.; Czajczyńska, D.; Stanchev, P.; Katsou, E.; Rostkowski, P.; Thorne, R.J.; Colón, J.; Ponsá, S.; Al-Mansour, F.; et al. Municipal solid waste management and waste-to-energy in the context of a circular economy and energy recycling in Europe. Energy 2017, 141, 2013-2044. [CrossRef]

(C) 2019 by the author. Licensee MDPI, Basel, Switzerland. This article is an open access article distributed under the terms and conditions of the Creative Commons Attribution (CC BY) license (http://creativecommons.org/licenses/by/4.0/). 